\title{
Prolonged breastfeeding and protective effects against the development of allergic rhinitis: a systematic review and
} meta-analysis*

\author{
Minh P. Hoang 1,2,3, Jompol Samuthpongtorn ${ }^{4}$, Kachorn Seresirikachorn 1,2, \\ Kornkiat Snidvongs ${ }^{1,2}$ \\ ' Department of Otolaryngology, Faculty of Medicine, Chulalongkorn University, Bangkok, Thailand \\ 2 Endoscopic Nasal and Sinus Surgery Excellent Center, King Chulalongkorn Memorial Hospital, Bangkok, Thailand \\ ${ }^{3}$ Department of Otolaryngology, Hue University of Medicine and Pharmacy, Hue University, Vietnam \\ ${ }^{4}$ Department of Anatomy, Faculty of Medicine, Chulalongkorn University, Bangkok, Thailand
}

Rhinology 60: 2, 82 - 91, 2022

https://doi.org/10.4193/Rhin21.274

* Received for publication:

July 24, 2021

Accepted: September 30, 2021

\begin{abstract}
Background: There is insufficient evidence to confirm the protective effects of prolonged breastfeeding against the development of allergic rhinitis (AR).

Methodology: A systematic review and meta-analysis was performed to assess the associations between prolonged breastfeeding and AR symptoms later in life. Comparisons were conducted between breastfeeding durations $<6$ months and $\geq 6$ months and between $<12$ months and $\geq 12$ months. Exclusive breastfeeding and nonexclusive breastfeeding were analysed separately. Outcomes were risks of AR development later in life.
\end{abstract}

Results: Twenty-three observational studies (161,611 children, age 2-18 years, 51.50\% male) were included. Two studies (9\%) were with high quality. Both exclusive and nonexclusive prolonged breastfeeding ( $\geq 6$ months) decreased the risk of AR. The long-term ( $\geq 12$ months) nonexclusive breastfeeding lowered the likelihood of AR compared to the $<12$ months. The long-term exclusive breastfeeding did not show the same protective effect; however, this result was restricted to only one study.

Conclusions: Exclusive breastfeeding and nonexclusive breastfeeding for $\geq 6$ months may have protective effects against the development of AR up to 18 years of age. The findings should be interpreted with caution given the limitation of low-quality observational studies.

Key words: allergic rhinitis, breastfeeding, prolonged breastfeeding, exclusive breastfeeding, children

\section{Introduction}

Allergic rhinitis (AR) is one of the most common atopic diseases worldwide ${ }^{(1)}$. Genetic and environmental factors during early infancy impact the development of allergic diseases ${ }^{(2-4)}$. Infant nutrition may influence the development of $A R^{(5-7)}$. Breast milk consists of immunological components that support the infant's immune system ${ }^{(2)}$. Immunomodulation induced by maternal antibodies in breast milk is different from infant formula ${ }^{(5,8)}$. Additionally, the immunomodulatory effect may come from human milk oligosaccharides via the immune and microbiome maturation ${ }^{(9,10)}$. Understanding the associations of breastfeeding with early-life immune system and susceptibility to $A R$ is essential. However, there is a lack of strong evidence supporting this matter.

The World Health Organization (WHO) recommends exclusive breastfeeding for the first six months of life ${ }^{(11)}$, and breastfeeding should continue with adequate complementary foods for up to two years ${ }^{(11,12)}$. The European Academy of Allergy and Clinical Immunology (EAACl) advocates exclusive breastfeeding suggesting that infants are breastfed with no other liquids or solid foods for at least four to six months as a preferred natural preventive medicine ${ }^{(13)}$. Current studies report inconsistent findings of the protective effects of prolonged breastfeeding against the development of $A R^{(7,12,14-17)}$. Recent meta-analyses are also lacking evidence ${ }^{(14,18,19)}$. This systematic review aims to assess the associations between the prolonged breastfeeding, for at least 
six months, and AR development later in life.

\section{Materials and methods}

The study protocol was registered on PROSPERO (reference number CRD42020216311). This systematic review adhered to The Preferred Reporting Items for Systematic Reviews and Meta-Analyses (PRISMA) ${ }^{(20)}$. Systematic searches on PubMed, EMBASE, Web of Science, and CENTRAL electronic databases were conducted from interception until 08 May 2021. ClinicalTrials.gov and WHO International Clinical Trials Registry Platform were searched to collect unpublished data. Manual searches were performed for the references of the included studies and additional sources. The search strategy is displayed in Table S1 (in the Supplement).

\section{Eligibility criteria}

Clinical studies with original data that assessed the association between breastfeeding and the development of AR were included. Study design, either observational (cross-sectional, casecontrol, cohort) or experimental (controlled trial) was accepted. AR could be diagnosed by any means e.g., the International Study of Asthma and Allergy in Children (ISAAC) questionnaire, clinical criteria, and allergy tests. Study participants could be identified by either prospective recruitment or from electronic medical records and health databases. There was no age restriction. Studies which assessed the patients with other allergies were included if the data of AR were reported separately from other allergies. Studies which included only the patients who were breastfed less than six months were excluded. Conference abstracts and non-English publications were excluded.

\section{Study selection process and data extraction}

Two review authors (MPH and JS) separately screened the titles and the abstracts of all identified studies based on the predetermined criteria. Full-text articles of the selected titles or abstracts were reviewed following the inclusion and exclusion criteria for the final selection. Two authors (MPH and KSe) independently extracted the data from the eligible studies. If there was incomplete data, the corresponding author of that study was contacted for further supporting information. During the data selection and extraction processes, any disagreements were resolved by discussing with the fourth reviewer (KSn) until reaching a consensus. The extracted data included: first author, year, study design, country, sample size, population, type and duration of breastfeeding, diagnostic tool of AR, control group, confounders, high-risk population, and quality score of the study. Breastfeeding duration in this study was categorized in accordance with the age that the breastfeeding stopped as follows: short-term ( $<6$ months), prolonged breastfeeding ( $\geq 6$ months), or long-term breastfeeding ( $\geq 12$ months).

\section{Outcome measures}

Risks of developing AR were assessed by analyzing the odds ratio (OR). There were four comparisons evaluated in this metaanalysis: 1 ) prolonged nonexclusive breastfeeding ( $\geq 6$ months) versus short-term nonexclusive breastfeeding ( $<6$ months), 2$)$ long-term nonexclusive breastfeeding ( $\geq 12$ months) versus less than 12 months nonexclusive breastfeeding, 3) prolonged exclusive breastfeeding ( $\geq 6$ months) versus short-term exclusive breastfeeding ( $<6$ months), and 4 ) long-term exclusive breastfeeding ( $\geq 12$ months) versus less than 12 months exclusive breastfeeding. To retrieve data of a single study reporting outcomes with multiple durations of breastfeeding, the risk of AR and new crude OR were calculated at two cut-off timepoints (6 months and 12 months). For studies in which prevalence was unavailable, the available crude OR and adjusted OR were extracted, using the reported value of the most appropriate category. To choose the applicable OR for a single study with multiple ages of outcome, the estimates for the oldest age of outcome were selected.

Quality of included studies

Two authors (MPH and JS) independently evaluated the quality of the included studies following the Newcastle-Ottawa scale (NOS)(21). Three domains were assessed, including selection, comparability, and outcome. The total score of NOS for cohort or case-control studies was nine and for cross-sectional studies was six. The quality of each study was graded according to the NOS score as follows: low-quality (score 0 to 4), medium-quality (score 5 to 7), and high-quality (score 8 to 9). The Grading of Recommendations, Assessment and Evaluation (GRADE) approach was used to evaluate quality of evidence as follows: high, moderate, low, and very low ${ }^{(22)}$. Data from observational studies were considered low-quality evidence unless there was plausible evidence to be upgraded ${ }^{(23)}$.

Data synthesis and statistical analysis Data were pooled for meta-analysis. OR and 95\% confidence interval $(\mathrm{Cl})$ were used for dichotomous data. Discrepancies in the risks of $A R$ among different studies were assessed using heterogeneity $\left(\mathrm{I}^{2}\right)$ statistic. An $\mathrm{I}^{2}$ of $<40 \%, 40-60 \%$ and $>60 \%$ represented low, moderate, and substantial heterogeneity. A fixed-effect model was used when the heterogeneity was low. A random-effects model was used if the heterogeneity was high, for a more conservative estimate of the differences. Funnel plot was used to assess publication bias. Egger's test was used to measure small-study effects for quantitative syntheses of at least ten studies. All statistical assessments were conducted using Review Manager (RevMan) version 5.4 and Stata 16.1 (StataCorp, College Station, TX, USA). 


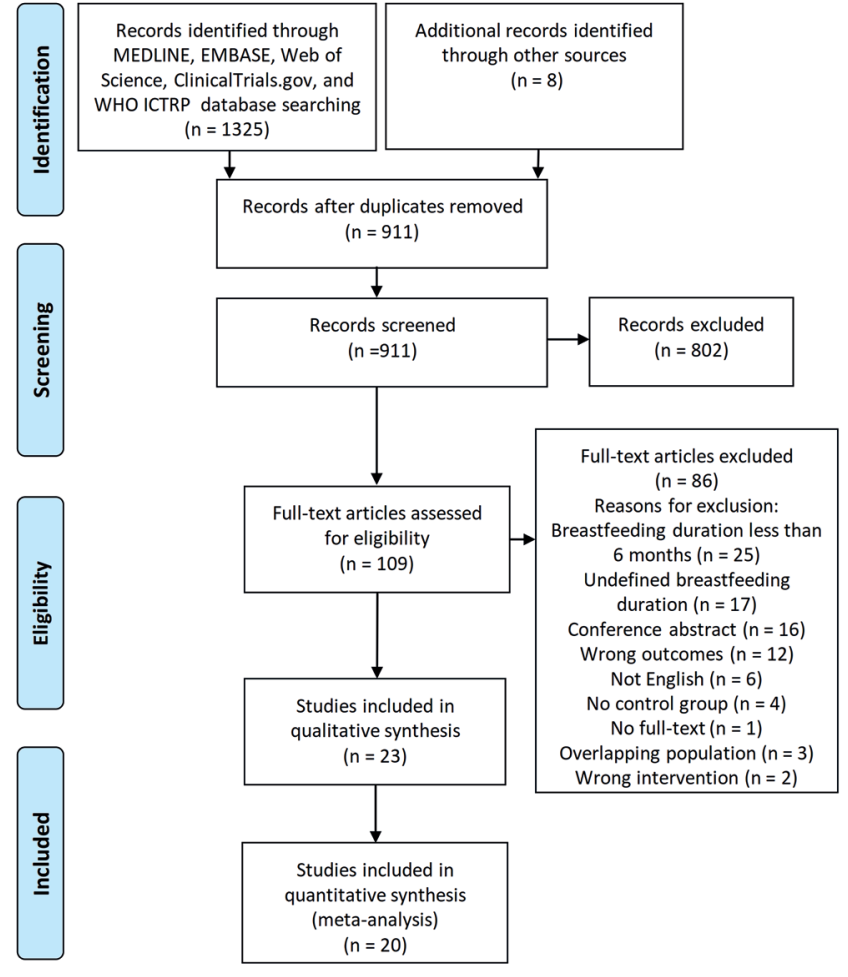

Figure 1. Flow diagram of study selection followed the Preferred Reporting Items for Systematic Reviews and Meta-Analyses (PRISMA) guidelines.

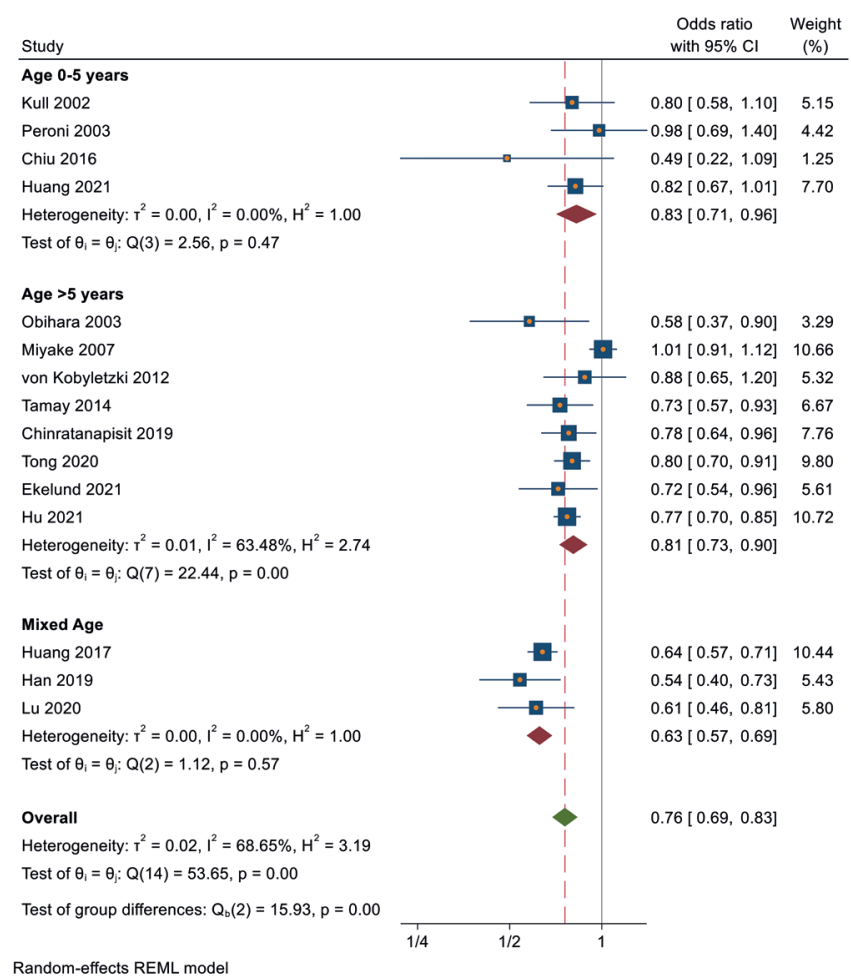

Figure 2. The risk of allergic rhinitis and subgroup analysis by the age of outcome: nonexclusive breastfeeding $\geq 6$ months vs $<6$ months.

\section{Subgroup analysis}

Subgroup analyses were performed to explore the heterogeneity by the following characteristics: study design (case-control, cross-sectional, cohort, experimental), age of AR outcome ( $\leq 5$ years, $>5$ years $)^{(24)}$, adjustment for confounding factors that affect the maturity of the immune system after breastfeeding (adequate adjustment, inadequate adjustment), region of the study (Asia, Europe, Africa, North America, South America, Australia), study quality (low, medium, high), AR diagnostic tool (confirmed by specific lgE tests, not confirmed by specific IgE tests), and available OR (unadjusted OR, adjusted OR). Adjustment for confounding factors was rated as adequate if a study adjusted any three of the five potential confounders (parental atopy, birth weight, smoking during pregnancy, socioeconomic status, and race/ethnicity) ${ }^{(16,25)}$.

\section{Results}

\section{Study selection}

The literature search yielded 911 studies. One hundred and nine studies were selected for full-text review. Twenty-three observational studies (nine cohort studies ${ }^{(6,26-33)}$ and 14 crosssectional studies ${ }^{(12,34-46)}$ ) were included for qualitative synthesis, of which 20 studies $^{(12,26-28,30-32,34-46)}$ were included in meta-analysis. A PRISMA flowchart is illustrated in Figure 1.

\section{Study characteristics}

There were 161,611 children below 18 (age 2-18 years, 51.50\% male) included in the analysis. The included studies were from three continents: Asia $(n=106,693)$, Europe $(n=54,057)$, and Africa ( $n=861)$. Characteristics of the included studies are presented in Table 1. Seven studies assessed children under five ${ }^{(26,29,31,34,37,38,46)}$. There were four studies that included specific populations: one study assessed rhinitis population ${ }^{(12)}$, two studies assessed population with HLA-conferred susceptibility to type 1 diabetes ${ }^{(29,33)}$, and one study assessed population with maternal history of asthma which was considered as a high-risk for developing $\mathrm{AR}^{(30)}$. The ISAAC questionnaire was the most common epidemiological tool for diagnosing AR used in 18 studies ${ }^{(6,27-29,31-42,44,46)}$. A skin prick test was used to define AR in three studies ${ }^{(12,30,38)}$. Atopic sensitization was investigated by specific lgE tests in nine studies ${ }^{(6,12,27,29-31,34,38,46)}$. Seventeen out of 23 studies had adequate adjustment for confounding variables $^{(6,12,27,28,30-36,40-44,46)}$.

\section{Nonexclusive breastfeeding $\geq 6$ months and its impact on the development of AR}

Eighteen studies assessed the effect of prolonged nonexclusive breastfeeding ( $\geq 6$ months) $)^{(6,12,26,28,29,31-36,39-44,46)}$. One study ${ }^{(33)}$ used hazard ratio (HR) and found no association with the risk of seasonal AR. Bion et al. ${ }^{(6)}$ assessed the effects of multiple breast- 
Table 1. Characteristics of the included studies.

\begin{tabular}{|c|c|c|c|c|c|c|c|c|c|c|}
\hline \multirow{2}{*}{$\begin{array}{l}\text { First author, } \\
\text { Year }\end{array}$} & \multirow[t]{2}{*}{ Country } & \multirow[t]{2}{*}{ Design } & \multirow{2}{*}{$\begin{array}{l}\text { Sample } \\
\text { size }\end{array}$} & \multirow{2}{*}{$\begin{array}{l}\text { Male/ } \\
\text { Female }\end{array}$} & \multirow{2}{*}{$\begin{array}{l}\text { Type } \\
\text { of BF }\end{array}$} & \multirow{2}{*}{$\begin{array}{c}\text { AR } \\
\text { Diagnostic } \\
\text { Tools }\end{array}$} & \multirow{2}{*}{$\begin{array}{c}\text { Age of } \\
\text { outcome }\end{array}$} & \multicolumn{2}{|c|}{ Odds ratio $(95 \% \mathrm{CI})$} & \multirow{2}{*}{$\begin{array}{c}\text { NOS score } \\
\text { QOS }\end{array}$} \\
\hline & & & & & & & & $\begin{array}{l}\geq 6 \text { vs }<6 \\
\text { (months) }\end{array}$ & $\begin{array}{c}\geq 12 \text { vs }<12 \\
\text { (months) }\end{array}$ & \\
\hline Kull(26) $^{(2602}$ & Sweden & Cohort & 4,089 & $2,065 / 2,024$ & NBF & $\begin{array}{l}\text { Question- } \\
\text { naire }\end{array}$ & Age 2 & $\begin{array}{c}0.80 \\
(0.58,1.09)\end{array}$ & NA & 7, Medium \\
\hline Peroni(34), 2003 & Italy & $\begin{array}{l}\text { Cross } \\
\text { sectional }\end{array}$ & 1,042 & $734 / 668$ & NBF & ISAAC & Age 3-5 & $\begin{array}{c}1.02 \\
(0.75,1.54)\end{array}$ & NA & 4, Low \\
\hline Obihara $^{(35)}, 2005$ & $\begin{array}{l}\text { South } \\
\text { Africa }\end{array}$ & $\begin{array}{l}\text { Cross } \\
\text { sectional }\end{array}$ & 861 & $687 / 654$ & NBF & ISAAC & Age 6-14 & $\begin{array}{c}0.58 \\
(0.37,0.90)^{*}\end{array}$ & $\begin{array}{c}0.50 \\
(0.29,0.89)^{*}\end{array}$ & 5, Medium \\
\hline \multirow[t]{2}{*}{ Miyake ${ }^{(36)}, 2007$} & Japan & $\begin{array}{l}\text { Cross } \\
\text { sectional }\end{array}$ & 24,077 & $\begin{array}{l}12,016 / \\
12,161\end{array}$ & NBF & ISAAC & Age 6-14 & $\begin{array}{c}1.01 \\
(0.91,1.11)^{*}\end{array}$ & NA & \\
\hline & & & & & EBF & & & NA & $\begin{array}{c}1.02 \\
(0.88,1.17)^{*}\end{array}$ & \\
\hline Ehlaye $^{(37)}, 2008$ & Qatar & $\begin{array}{l}\text { Cross } \\
\text { sectional }\end{array}$ & 1,278 & $632 / 646$ & EBF & ISAAC & Age 0-5 & $\begin{array}{c}0.56 \\
(0.44,0.71)\end{array}$ & NA & 3, Low \\
\hline Kramer ${ }^{(27)}, 2009$ & Belarus & Cohort & 13,889 & $7,181 / 6,708$ & EBF & ISAAC & Age 6.5 & $\begin{array}{c}0.80 \\
(0.47,1.38)^{*}\end{array}$ & NA & 8, High \\
\hline $\begin{array}{l}\text { Siriaksorn }{ }^{(38)} \\
2011\end{array}$ & Thailand & $\begin{array}{l}\text { Cross } \\
\text { sectional }\end{array}$ & 2,301 & $1,289 / 1,012$ & EBF & ISAAC, SPT & Age 3-5 & $\begin{array}{c}0.17 \\
(0.03,0.88)\end{array}$ & NA & 4, Low \\
\hline $\begin{array}{l}\text { von Kobyletzki } \\
\text { (28), } 2012\end{array}$ & Sweden & Cohort & 3,125 & $1,579 / 1,546$ & NBF & ISAAC & Age 6-7 & $\begin{array}{c}0.88 \\
(0.65,1.20)\end{array}$ & NA & 6, Medium \\
\hline Nwaru ${ }^{(29)}, 2013$ & Finland & Cohort & 3,781 & $1,993 / 1,788$ & NBF & ISAAC & Age 5 & NA & NA & 7, Medium \\
\hline Tamay ${ }^{(39)}, 2014$ & Turkey & $\begin{array}{l}\text { Cross } \\
\text { sectional }\end{array}$ & 9,807 & $4,972 / 4,835$ & NBF & ISAAC & Age 6-7 & $\begin{array}{c}0.73 \\
(0.57,0.93)\end{array}$ & NA & 4, Low \\
\hline $\begin{array}{l}\text { Jelding-Danne- } \\
\text { mand }^{(30)}, 2015\end{array}$ & $\begin{array}{l}\text { Den- } \\
\text { mark }\end{array}$ & Cohort & 389 & $160 / 229$ & EBF & ISAAC, SPT & Age 7 & $\begin{array}{c}0.30 \\
(0.07,1.28)\end{array}$ & NA & 8, High \\
\hline Bion ${ }^{(\mathrm{a})(6)}, 2016$ & UK & Cohort & 1,536 & $786 / 750$ & NBF & ISAAC & Age 18 & NA & NA & 8, High \\
\hline Bion $^{(b) / 6)}, 2016$ & UK & Cohort & 957 & $495 / 462$ & NBF & ISAAC & Age 10 & NA & NA & 8, High \\
\hline \multirow[t]{2}{*}{$\mathrm{Chiu}^{(31)}, 2016$} & Taiwan & Cohort & 186 & $83 / 103$ & NBF & ISAAC & Age 4 & $\begin{array}{c}0.49 \\
(0.22,1.09)\end{array}$ & NA & 7, Medium \\
\hline & & & & & EBF & & & NA & NA & \\
\hline \multirow[t]{2}{*}{ Huang ${ }^{(40)}, 2017$} & China & $\begin{array}{l}\text { Cross } \\
\text { sectional }\end{array}$ & 13,289 & $6,536 / 6,753$ & NBF & ISAAC & Age 4-6 & $\begin{array}{c}0.80 \\
(0.71,0.91)^{*}\end{array}$ & NA & 5, Medium \\
\hline & & & & & EBF & & & $\begin{array}{c}0.56 \\
(0.45,0.69)^{*}\end{array}$ & NA & \\
\hline $\begin{array}{l}\text { Chinratanapi- } \\
\text { sit }^{(41)}, 2019\end{array}$ & Thailand & $\begin{array}{l}\text { Cross } \\
\text { sectional }\end{array}$ & 6,291 & $3,278 / 3,013$ & NBF & GAN/ISAAC & Age 6-7 & $\begin{array}{c}0.78(0.64 \\
0.96)\end{array}$ & NA & 4, Low \\
\hline $\operatorname{Han}^{(12)}, 2019$ & Korea & $\begin{array}{l}\text { Cross } \\
\text { sectional }\end{array}$ & 1,374 & $941 / 433$ & NBF & $\begin{array}{l}\text { Rhinitis } \\
\text { symptoms, } \\
\text { SPT }\end{array}$ & Age 4-12 & $\begin{array}{c}0.54 \\
(0.40,0.73)\end{array}$ & $\begin{array}{c}0.49 \\
(0.36,0.68)\end{array}$ & 5, Medium \\
\hline $\mathrm{Li}^{(45)}, 2020$ & China & $\begin{array}{l}\text { Cross } \\
\text { sectional }\end{array}$ & 2,126 & $1,093 / 1033$ & EBF & $\begin{array}{l}\text { ATS-DLD- } \\
\text { 78-C }\end{array}$ & Age 6-11 & $\begin{array}{c}0.63 \\
(0.48,0.82)^{*}\end{array}$ & NA & 2, Low \\
\hline $\mathrm{Lu}^{(42)}, 2020$ & China & $\begin{array}{l}\text { Cross } \\
\text { sectional }\end{array}$ & 39,782 & $\begin{array}{c}20,633 / \\
19,149\end{array}$ & NBF & ISAAC & Age 3-6 & $\begin{array}{c}0.61 \\
(0.46,0.81)\end{array}$ & NA & 4, Low \\
\hline Tong $^{(43)}, 2020$ & China & $\begin{array}{l}\text { Cross } \\
\text { sectional }\end{array}$ & 5,550 & $2,993 / 2,557$ & NBF & $\begin{array}{l}\text { Question- } \\
\text { naire }\end{array}$ & Age 6-12 & $\begin{array}{c}0.80 \\
(0.70,0.91)\end{array}$ & NA & 4, Low \\
\hline Ekelund ${ }^{(32)}, 2021$ & Norway & Cohort & 6,796 & $3,379 / 3,417$ & NBF & ISAAC & Age 6 & $\begin{array}{c}0.77 \\
(0.58,1.04)\end{array}$ & NA & 7, Medium \\
\hline $\mathrm{Hu}^{(44)}, 2021$ & China & $\begin{array}{l}\text { Cross } \\
\text { sectional }\end{array}$ & 10,464 & $5,464 / 5,000$ & NBF & ISAAC & Age 6-11 & $\begin{array}{c}0.77 \\
(0.70,0.85)\end{array}$ & NA & 3, Low \\
\hline Huang(46), 2021 & Taiwan & $\begin{array}{l}\text { Cross } \\
\text { sectional }\end{array}$ & 3,192 & $1,725 / 1,467$ & NBF & ISAAC & Age $<6$ & $\begin{array}{c}0.82 \\
(0.67,1.01)\end{array}$ & NA & 4, Low \\
\hline $\begin{array}{l}\text { Hummel }{ }^{(33)}, \\
2021\end{array}$ & $\begin{array}{l}\text { Multi- } \\
\text { coun- } \\
\text { tries }\end{array}$ & Cohort & 8615 & $4390 / 4225$ & NBF & $\begin{array}{l}\text { Physicians' } \\
\text { diagnosis }\end{array}$ & $\begin{array}{c}\text { Age } 8.3 \\
\text { (IQR: } 2.8- \\
10.2 \text { ) }\end{array}$ & $\begin{array}{c}\text { Hazard ratio } \\
0.87 \\
(0.70,1.08)\end{array}$ & $\begin{array}{c}\text { Hazard ratio } \\
0.91 \\
(0.70,1.19)\end{array}$ & 7, Medium \\
\hline
\end{tabular}


Table 2. Subgroup analyses of nonexclusive breastfeeding for $\geq 6$ months vs $<6$ months and risk of allergic rhinitis.

\begin{tabular}{|c|c|c|c|}
\hline Subgroup & $\begin{array}{l}\text { Stud- } \\
\text { ies (n) }\end{array}$ & $\begin{array}{l}\text { Odds ratio } \\
\text { (95\% CI) }\end{array}$ & P value \\
\hline $\begin{array}{l}\text { Study design } \\
\text { Cohort } \\
\text { Cross-sectional }\end{array}$ & $\begin{array}{c}5 \\
10\end{array}$ & $\begin{array}{l}0.76(0.66,0.88) \\
0.76(0.69,0.85)\end{array}$ & 0.92 \\
\hline $\begin{array}{l}\text { Age of outcome } \\
\leq 5 \text { years } \\
>5 \text { years } \\
\text { Mixed Age }\end{array}$ & $\begin{array}{l}4 \\
8 \\
3\end{array}$ & $\begin{array}{l}0.83(0.71,0.96) \\
0.81(0.73,0.90) \\
0.63(0.57,0.69)\end{array}$ & $<0.01$ \\
\hline $\begin{array}{l}\text { Adjustment for confounders } \\
\text { Adequate adjustment } \\
\text { Inadequate adjustment }\end{array}$ & $\begin{array}{c}13 \\
2\end{array}$ & $\begin{array}{l}0.76(0.68,0.84) \\
0.76(0.62,0.92)\end{array}$ & 1.00 \\
\hline $\begin{array}{l}\text { Region } \\
\text { Africa } \\
\text { Asia } \\
\text { Europe }\end{array}$ & $\begin{array}{l}1 \\
9 \\
5\end{array}$ & $\begin{array}{l}0.58(0.37,0.90) \\
0.74(0.65,0.85) \\
0.80(0.70,0.91)\end{array}$ & 0.36 \\
\hline $\begin{array}{l}\text { Quality of study } \\
\text { Medium quality } \\
\text { Low quality }\end{array}$ & $\begin{array}{l}8 \\
7\end{array}$ & $\begin{array}{l}0.73(0.61,0.87) \\
0.78(0.73,0.83)\end{array}$ & 0.49 \\
\hline $\begin{array}{l}\text { AR diagnostic tools } \\
\text { Specific IgE tests } \\
\text { No specific lgE tests }\end{array}$ & $\begin{array}{c}1 \\
14\end{array}$ & $\begin{array}{l}0.54(0.40,0.73) \\
0.77(0.71,0.85)\end{array}$ & 0.02 \\
\hline $\begin{array}{l}\text { Available Odds ratio } \\
\text { Adjusted } \\
\text { Unadjusted }\end{array}$ & $\begin{array}{c}10 \\
6\end{array}$ & $\begin{array}{l}0.77(0.73,0.82) \\
0.72(0.57,0.91)\end{array}$ & 0.57 \\
\hline
\end{tabular}

Abbreviations: $\mathrm{Cl}$, Confidence interval
Table 3. Subgroup analyses of exclusive breastfeeding for $\geq 6$ months vs $<6$ months and risk of allergic rhinitis.

\begin{tabular}{|c|c|c|c|}
\hline Subgroup & $\begin{array}{l}\text { Stud- } \\
\text { ies }(n)\end{array}$ & $\begin{array}{l}\text { Odds ratio } \\
\text { (95\% CI) }\end{array}$ & P value \\
\hline $\begin{array}{l}\text { Study design } \\
\text { Cohort } \\
\text { Cross-sectional }\end{array}$ & $\begin{array}{l}2 \\
4\end{array}$ & $\begin{array}{l}0.71(0.43,1.18) \\
0.57(0.49,0.66)\end{array}$ & 0.40 \\
\hline $\begin{array}{l}\text { Age of outcome } \\
\leq 5 \text { years } \\
>5 \text { years } \\
\text { Mixed Age }\end{array}$ & $\begin{array}{l}2 \\
3 \\
1\end{array}$ & $\begin{array}{l}0.55(0.43,0.69) \\
0.65(0.51,0.82) \\
0.54(0.42,0.69)\end{array}$ & 0.51 \\
\hline $\begin{array}{l}\text { Adjustment for confounders } \\
\text { Adequate adjustment } \\
\text { Inadequate adjustment }\end{array}$ & $\begin{array}{l}3 \\
3\end{array}$ & $\begin{array}{l}0.57(0.46,0.71) \\
0.58(0.49,0.70)\end{array}$ & 0.88 \\
\hline $\begin{array}{l}\text { Region } \\
\text { Asia } \\
\text { Europe }\end{array}$ & $\begin{array}{l}4 \\
2\end{array}$ & $\begin{array}{l}0.57(0.49,0.66) \\
0.71(0.43,1.18)\end{array}$ & 0.40 \\
\hline $\begin{array}{l}\text { Quality of study } \\
\text { High quality } \\
\text { Medium quality } \\
\text { Low quality }\end{array}$ & $\begin{array}{l}2 \\
1 \\
3\end{array}$ & $\begin{array}{l}0.71(0.43,1.18) \\
0.54(0.42,0.69) \\
0.58(0.49,0.70)\end{array}$ & 0.63 \\
\hline $\begin{array}{l}\text { AR diagnostic tools } \\
\text { Specific lgE tests } \\
\text { No specific lgE tests }\end{array}$ & $\begin{array}{l}2 \\
4\end{array}$ & $\begin{array}{l}0.24(0.08,0.71) \\
0.59(0.51,0.67)\end{array}$ & 0.11 \\
\hline $\begin{array}{l}\text { Available Odds ratio } \\
\text { Adjusted } \\
\text { Unadjusted }\end{array}$ & $\begin{array}{l}3 \\
3\end{array}$ & $\begin{array}{l}0.60(0.46,0.77) \\
0.57(0.48,0.67)\end{array}$ & 0.77 \\
\hline
\end{tabular}

Abbreviations: $\mathrm{Cl}$, Confidence interval feeding durations without reporting the raw data for recalculating the crude odds ratio. Nwaru et al. ${ }^{(29)}$ used inappropriate cutoff timepoints (five and 9.5 months) of breastfeeding duration in which data were unable to be pooled in the meta-analysis. The pooled data from 15 studies $(n=126,708)$ showed a significant association between nonexclusive breastfeeding for at least six months and its protective effects against the development of AR (OR 0.76; 95\% Cl 0.69, 0.83; $\mathrm{p}<0.01)^{(12,26-28,31,34-36,38-43,46)}$ (Figure 2). The GRADE rating was very low quality due to substantial heterogeneity (I ${ }^{2}$ of $69 \%$ ) and high risk of bias (Table 4 ).

\section{Nonexclusive breastfeeding $\geq 12$ months and its impact on} the development of AR

Four studies assessed the effect of long-term nonexclusive breastfeeding ( $\geq 12$ months) $)^{(12,33,35,36)}$. One study ${ }^{(33)}$ reported the association with the risk of developing seasonal AR using hazard model but the data was not convertible. The pooled data from three cross-sectional studies (26,312 children) showed a signifi- cant association between nonexclusive breastfeeding for at least 12 months and its protective effects against the development of AR (OR 0.63; 95\% Cl 0.41, 0.97; $p<0.01)^{(12,35,36)}$ (Figure 3). The GRADE rating was very low quality due to substantial heterogeneity ( $I^{2}$ of $82 \%$, Table 4$)$.

\section{Exclusive breastfeeding $\geq 6$ months and its impact on the development of AR}

Seven observational studies assessed the sole protective effects of prolonged exclusive breastfeeding ( $\geq 6$ months) vs $<6$ months $s^{(27,30,31,37,38,40,45)}$. Only two studies ${ }^{(27,40)}$ followed the definition of exclusive breastfeeding by the WHO. Three studies ${ }^{(30,31,37)}$ modified the definition while the other two ${ }^{(38,45)}$ did not mention the definition of exclusive breastfeeding (Table S2 in the Supplement). Data of exclusive breastfeeding could not be extracted separately from mixed types of breastfeeding in one study ${ }^{(31)}$. The pooled data of six studies $(33,272$ children) showed statistically significant protective effects against AR in children who

Footnote Table 1: * recalculated crude odds ratio.

Abbreviations: BF, Breastfeeding; NBF, Nonexclusive breastfeeding; EBF, Exclusive breastfeeding; ISAAC, International Study of Asthma and Allergies in Childhood questionnaire; GAN, The Global Asthma Network; ATS-DLD-78-C, American Thoracic Society's Division of Lung Diseases; NOS, The Newcastle-Ottawa Scale; SPT, Skin prick test; $\mathrm{Cl}$, Confidence interval. 
Table 4. Certainty of the evidence (GRADE).

\begin{tabular}{|c|c|c|c|c|c|c|c|c|c|}
\hline $\begin{array}{c}\text { Outcomes AR } \\
\leq 18 \text { years }\end{array}$ & $\begin{array}{l}\text { Studies } \\
\text { (n) }\end{array}$ & $\begin{array}{l}\text { Risk of } \\
\text { bias }\end{array}$ & Inconsistency & Indirectness & Imprecision & $\begin{array}{l}\text { Publication } \\
\text { bias }\end{array}$ & $\begin{array}{l}\text { Sample } \\
\text { size }\end{array}$ & $\begin{array}{l}\text { Effect size } \\
\text { OR }(95 \% \mathrm{CI})\end{array}$ & Quality \\
\hline \multicolumn{10}{|c|}{ Nonexclusive breastfeeding } \\
\hline$\geq 6$ vs $<6$ months & 15 & Certain & $\begin{array}{l}\text { Serious incon- } \\
\text { sistency }\end{array}$ & $\begin{array}{l}\text { No serious } \\
\text { indirectness }\end{array}$ & $\begin{array}{l}\text { No serious } \\
\text { imprecision }\end{array}$ & Uncertain & 126,708 & $\begin{array}{c}0.76 \\
(0.69,0.83)\end{array}$ & $\begin{array}{c}+--- \\
\text { Very low }\end{array}$ \\
\hline$\geq 12$ vs $<12$ months & 3 & Uncertain & $\begin{array}{l}\text { Serious incon- } \\
\text { sistency }\end{array}$ & $\begin{array}{l}\text { No serious } \\
\text { indirectness }\end{array}$ & $\begin{array}{l}\text { Serious im- } \\
\text { precision }\end{array}$ & Uncertain & 26,312 & $\begin{array}{c}0.63 \\
(0.41,0.97)\end{array}$ & $\begin{array}{c}+--- \\
\text { Very low }\end{array}$ \\
\hline \multicolumn{10}{|c|}{ Exclusive breastfeeding } \\
\hline$\geq 6$ vs $<6$ months & 6 & Uncertain & $\begin{array}{c}\text { No serious } \\
\text { inconsistency }\end{array}$ & $\begin{array}{l}\text { No serious } \\
\text { indirectness }\end{array}$ & $\begin{array}{l}\text { No serious } \\
\text { imprecision }\end{array}$ & Uncertain & 33,272 & $\begin{array}{c}0.60 \\
(0.50,0.85)\end{array}$ & $\begin{array}{c}++-- \\
\text { Low }\end{array}$ \\
\hline$\geq 12$ vs $<12$ months & 1 & Certain & $\begin{array}{l}\text { No serious } \\
\text { inconsistency }\end{array}$ & $\begin{array}{l}\text { No serious } \\
\text { indirectness }\end{array}$ & $\begin{array}{l}\text { No serious } \\
\text { imprecision }\end{array}$ & Uncertain & 11,916 & $\begin{array}{c}0.89 \\
(0.77,1.04)\end{array}$ & $\begin{array}{c}+--- \\
\text { Very low }\end{array}$ \\
\hline
\end{tabular}

AR, Allergic rhinitis; OR, Odds ratio; $\mathrm{Cl}$, Confidence interval.

were exclusively breastfed for $\geq 6$ months (OR $0.58 ; 95 \% \mathrm{Cl} 0.50$, $\left.0.66 ; \mathrm{p}<0.01 ; \mathrm{I}^{2}=0 \%\right)^{(27,30,37,38,40,45)}$ (Figure 4). The GRADE rating was low quality (Table 4).

Exclusive breastfeeding $\geq 12$ months and its impact on the development of AR

One study assessed the sole protective effects against AR in exclusively breastfed children for $\geq 12$ months vs $<12$ months ${ }^{(36)}$. Exclusive breastfeeding for $\geq 12$ months was not associated with a lower likelihood of developing AR (OR 0.89; 95\% CI 0.77, 1.04; $\mathrm{p}=0.14)$. The GRADE rating was very low quality due to high risk of bias (Table 4).

\section{Subgroup analysis}

Subgroup analyses were performed to explore the plausibility of heterogeneity (Tables 2-3, Figures S1-12 in the Supplement). Subgroup analysis by AR diagnostic criteria ( $p=0.02$, Table 2 ) showed significant associations of prolonged nonexclusive breastfeeding ( $\geq 6$ months). The protective effects were greater when the included studies used specific lgE tests (OR 0.54; $95 \%$ $\mathrm{Cl} 0.40,0.73)$ than other tests $(\mathrm{OR} 0.77 ; 95 \% \mathrm{Cl} 0.71,0.85), \mathrm{p}=0.02$. Subgroup analysis by the age of AR outcome also showed the difference $(p<0.01)$, though the difference in three subgroups was due to the subgroup of mixed age. There was no difference between the subgroup of age 0-5 and age $>5$ years old for both nonexclusive (Figure 2 ) and exclusive breastfeeding $\geq 6$ months (Figure 4). There were no associations demonstrated in other subgroup analyses, including by study design, adjustment for confounding factors, study quality, and available OR.

\section{Risk of bias assessment}

\section{Quality of included studies}

There were 10 (43\%) studies with low quality, 11 (48\%) with medium quality, and two (9\%) with high quality (Table 1, Tables S3-S4 in the Supplement). The cross-sectional studies had a low score in ascertainment of exposure due to recall bias. All eight cohort studies had moderate-to-high quality.

\section{Quality assessment of outcomes}

A funnel plot and Egger's test with $\mathrm{p}=0.17$ indicated no publication bias for the meta-analysis of nonexclusive breastfeeding for at least six months (Figure S18 in the Supplement).

\section{Sensitivity analysis}

When there were only observational studies with mixed populations included for qualitative synthesis and meta-analyses, there was a concern whether the study inclusion should be restricted by the study's quality and the general population, or the model selection impacted the results. A sensitivity analysis was performed by undertaking the meta-analysis twice: 1 ) the meta-analysis that included all studies; 2 ) the meta-analysis that included only those with medium and high quality; 3 ) the metaanalysis that included only those with general population. After removing low-quality studies, according to the NOS score, both sensitivity analyses in nonexclusive breastfeeding (OR of 0.73 ; $95 \% \mathrm{Cl} 0.61,0.87 ;\left.\right|^{2}=78 \%$ ) and exclusive breastfeeding (OR 0.57; $95 \% \mathrm{Cl} 0.46,0.71 ; 1^{2}=18 \%$ ) for at least six months did not impact the total effects (Figures S13-S14 in the Supplement). Similarly, omission of studies with high-risk populations did not change the total effects in both nonexclusive breastfeeding (OR of 0.77 ; $95 \% \mathrm{Cl} 0.71,0.85 ; \mathrm{I}^{2}=65 \%$ ) and exclusive breastfeeding (OR of $0.58 ; 95 \% \mathrm{Cl} 0.51,0.67 ; \mathrm{I}^{2}=4 \%$ ) (Figures S15-S16 in the Supplement). The random-effects model did not impact the total effect of exclusive breastfeeding for at least six months. However, the protective effect was not displayed up to 5 years of age (Figure S17 in the Supplement).

\section{Discussion}

Breastfeeding has many benefits for children, including protections against many diseases (e.g., infectious diseases, 


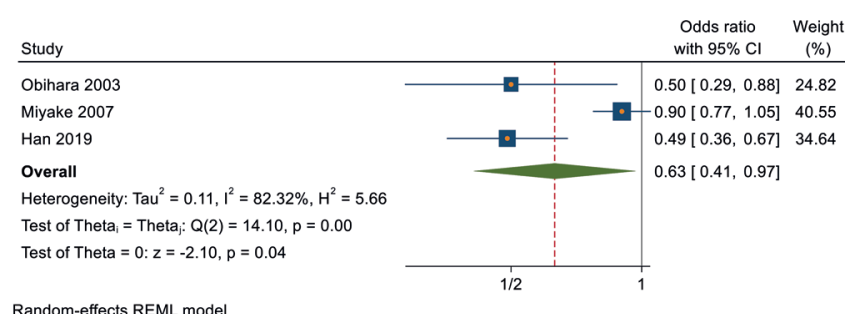

Random-effects REMLmodel

Figure 3. The risk of allergic rhinitis: nonexclusive breastfeeding $\geq 12$ months vs $<12$ months.

autoimmune diseases, and obesity $\left.{ }^{(47)}\right)$. It also benefits mothers, such as helping decrease the incidence of breast cancer and diabetes and helping space pregnancies in nursing women ${ }^{(47)}$. Active compounds found in breast milk can mature the adaptive immunity ${ }^{(31)}$. Interferon-gamma in breast milk stimulates the $T$ helper 1 (Th1) inflammatory response and suppresses the Th2 allergic response $\mathrm{e}^{(48)}$. Other immunological compounds such as long-chain polyunsaturated fatty acids and osteoprotegerin can promote antigen-specific tolerance, the Th 1 and Th 2 response, and regulate the Th1/Th2 balance ${ }^{(48)}$. Breastfeeding intensifies innate immunity by regulating the gut microbiome diversity which is thought to mediate the Th1/Th2 balance ${ }^{(31)}$. Shortchain fatty acids are microbiota-generated metabolites that can influence peripheral $\mathrm{T}$ cells, especially regulatory $\mathrm{T}$ (Treg) cells, by inhibiting histone deacetylases. Short-chain fatty acids can adjust the frequency and function of Treg in vivo ${ }^{(49)}$. Breastfed neonates have a two-fold higher proportion of Treg cells and decreased inflammatory cytokine production compared to those who received formula milk(8). With these immunological effects, breastfeeding may have benefits on protection against allergic diseases.

This systematic review and meta-analysis demonstrated the protective effect of prolonged breastfeeding ( $\geq 6$ months) against the development of AR when compared to short-term breastfeeding ( $<6$ months). The likelihood of developing AR was lower in children who were exclusively breastfed for at least six months compared to those with prolonged nonexclusive breastfeeding. The non-overlapping of the two odds ratios indicated statistical significance. The authors would like to stress that prolonged breastfeeding was generally defined as breastfed for greater than 6 months. Therefore, the number of manuscripts including breastfeeding for 12 months is certainly inferior in number and quality compared to the ones that analysed breastfeeding at 6 months. Long-term nonexclusive breastfeeding (at least 12 months) also had a significant impact in reducing the risk of AR. All three included studies in this meta-analysis were from Asia, representing the shorter breastfeeding duration in Europe $^{(47)}$.

The protective effects continued up to 18 years. In this study, subgroup analysis by age of AR outcome ( $\leq 5$ years, $>5$ years)

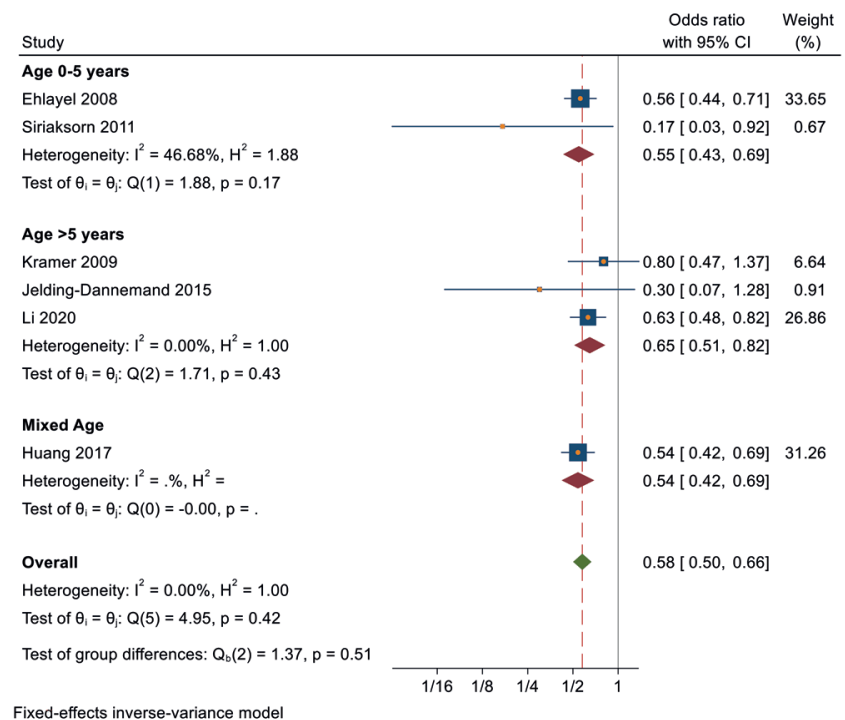

Figure 4. The risk of allergic rhinitis and subgroup analysis by the age of outcome: exclusive breastfeeding $\geq 6$ months vs $<6$ months.

was performed to assess the atopic march at five years of age. The progression of atopic disorders from atopic dermatitis and food allergy to allergic rhinitis and asthma develops at certain ages $^{(24)}$. Some children with atopic march may persist for several years, whereas others may resolve with increasing age. We therefore would like to assess if there was any subgroup difference between the age of AR outcome of 5 years and 18 years. To date, there have been three meta-analyses assessing the effects of breastfeeding on the development of $\mathrm{AR}^{(14,18,19)}$. Mimouni et al. ${ }^{(18)}$ pooled data from six prospective studies and showed that breastfeeding for at least three months had a protective effect against AR in children under five years of age. Lodge et al. ${ }^{(14)}$ extracted data from 16 studies with different cut-off timepoints for breastfeeding duration and mixed types of breastfeeding. They found similar findings, but the protective effects did not continue after five years of age ${ }^{(14)}$. In 2018, a comprehensive meta-analysis used different timepoints for exclusive breastfeeding and did not show any associations between exclusive breastfeeding and the development of $\mathrm{AR}^{(19)}$. None of the three previous meta-analyses followed the WHO guidelines in choosing the timepoints for breastmilk duration. Classifications of breastfeeding duration were not clearly defined in the earlier meta-analyses. The pooled data from unclear classifications may affect the results. Instead of 'more vs less' or 'ever vs never', the more specific term such as ' $\geq 6$ months vs $<6$ months' may result in more accurate data.

In the first years of life, most nasal symptoms are related to viral infection rather than allergy ${ }^{(50)}$. Although epidemiological tools, such as the ISAAC questionnaire, cannot distinguish these two conditions ${ }^{(51)}$, the current epidemiological knowledge of pediatric AR is derived from ISAAC questionnaire ${ }^{(52)}$. In this review, the core ISAAC questions for diagnosis of AR were modified and 
used in different self-reported questionnaires and surveys. How the prevalence of allergic rhinitis was defined among included studies was heterogeneous, leading to a limitation of our review. Kim et al. ${ }^{(53)}$ found that the omission of a detailed anamnesis and IgE testing resulted in low accuracy of the ISAAC survey. Zacharasiewicz et al. ${ }^{(54)}$ noted that only fifty percent of rhinitis symptoms are contributable to atopy. The variability has been announced worldwide without a clear explanation ${ }^{(55)}$. Our subgroup analysis by AR diagnostic criteria indicated the difference in protective effects between specific lgE tests and epidemiologic tools. For future studies, the combination of allergy testing and epidemiological tools for diagnosing AR should be considered. Specific lgE tests detect allergen sensitization after environmental exposures and contribute to the early prevention of allergic diseases.

The strengths of our meta-analysis were that we focused on the duration of breastfeeding and analyzed the nonexclusive breastfeeding separately from exclusive breastfeeding to explore the sole effect of each type. Both types of prolonged breastfeeding (>6 months) reduced the likelihood of developing AR. Sensitivity analyses by removing low-quality studies did not change the effect, indicating uncertain risk of bias. Subgroup analysis by recalculated crude OR did not show any significant difference in the protective effect of breastfeeding. Furthermore, subgroup analysis by adjustment for confounding factors following the criteria of Kramer ${ }^{(16)}$ did not suggest a well-designed study with assessment for many essential confounders.

The limitation of this study was the low to medium quality of the included studies. The overall quality of evidence was low. Most included studies had bias on ascertainment of exposure. The inconsistency in methodology influenced the quality of evidence. Reverse causation may happen when a child with a family history with atopy or early allergic signs tends to receive prolonged breastfeeding. A few studies explored the effect of reverse causation and had conflicting results. Jelding-Dannemand et al. ${ }^{\left({ }^{(0)}\right.}$ found that the onset of allergic diseases and SPT before finishing the exclusive breastfeeding did not change the results. On the other hand, Kusunoki et al. ${ }^{(56)}$ demonstrated a longer breastfeeding duration in a population with high risk of allergic diseases compared to those with low risk. The incidence of allergic rhinitis may be affected by many factors. The discrepancy in the definition of exclusive breastfeeding and the criteria for
AR diagnosis may cause bias. In addition, recall bias of breastfeeding duration and solid food introduction causes inconsistent conclusions. Large population-based prospective cohorts using an appropriate methodology for AR diagnostic criteria and ascertainment of breast milk consumption such as secure records, structured interviews, written self-report are required. Rigorous assessment and long-term follow-up in further studies strengthen the evidence of our study. Despite the low- to very low-quality of evidence following GRADE, this meta-analysis highlights the benefits of breastfeeding for at least six months on AR prevention.

\section{Conclusion}

Prolonged breastfeeding (at least six months) provided protection against allergic rhinitis. This finding is in accordance with the World Health Organization recommendation that every infant should be breastfed for at least six months. Breastfed children may receive essential benefits such as prevention of uncommunicable diseases like allergic rhinitis. The overall quality of evidence was low so these findings should be interpreted with caution. Most included studies had a limitation on ascertainment of exposure. Recall bias and poor methodology of observational studies may influence these protective effects of prolonged breastfeeding.

\section{Funding}

This is an unfunded project.

\section{Authorship contribution}

MPH: study design, search, study selection, data collection, data analysis, drafting the article, and final approval. JS: search, study selection, data collection, revising the article, and final approval. KSe: search, study selection, data collection, revising the article, and final approval. KSn: conception, study design, data analysis, drafting the article, and final approval.

\section{Conflict of interest}

Kornkiat Snidvongs received Honoraria for speaking at symposia from Organon, Mylan, and Menarini. Minh P. Hoang, Jompol Samuthpongtorn, and Kachorn Seresirikachorn declare that they have no conflict of interest.

\section{References}

1. Brozek JL, Bousquet J, Agache I, et al. Allergic Rhinitis and its Impact on Asthma (ARIA) guidelines-2016 revision. J Allergy Clin Immunol. 2017; 140(4): 950-958.

2. Wise SK, Lin SY, Toskala E, et al. International Consensus Statement on Allergy and Rhinology: Allergic Rhinitis. Int Forum Allergy Rhinol. 2018; 8(2): 108-352.
3. Wang DY. Risk factors of allergic rhinitis: genetic or environmental? Ther Clin Risk Manag. 2005; 1(2): 115-123.

4. Testa D, Bari MDI, Nunziata M, et al. Allergic rhinitis and asthma assessment of risk factors in pediatric patients: A systematic review. Int J Pediatr Otorhinolaryngol. 2020; 129: 109759.

5. Sjogren YM, Duchen K, Lindh F, Bjorksten B,
Sverremark-Ekstrom E. Neutral oligosaccharides in colostrum in relation to maternal allergy and allergy development in children up to 18 months of age. Pediatr Allergy Immunol. 2007; 18(1): 20-26.

6. Bion V, Lockett GA, Soto-Ramirez N, et al. Evaluating the efficacy of breastfeeding guidelines on long-term outcomes for allergic disease. Allergy. 2016; 71(5): 661-670. 
7. Friedman NJ, Zeiger RS. The role of breastfeeding in the development of allergies and asthma. J Allergy Clin Immunol. 2005; 115(6): 1238-1248.

8. Wood H, Acharjee A, Pearce $H$, et al. Breastfeeding promotes early neonatal regulatory T-cell expansion and immune tolerance of non-inherited maternal antigens. Allergy. 2021; 76(8): 2447-2460.

9. Sprenger N, Odenwald H, Kukkonen AK, Kuitunen M, Savilahti E, Kunz C. FUT2dependent breast milk oligosaccharides and allergy at 2 and 5 years of age in infants with high hereditary allergy risk. Eur J Nutr. 2017; 56(3): 1293-1301.

10. Zuurveld M, van Witzenburg NP, Garssen $J$, et al. Immunomodulation by Human Milk Oligosaccharides: The Potential Role in Prevention of Allergic Diseases. Front Immunol. 2020; 11:801.

11. World Health Organization and UNICEF. Global strategy for infant and young child feeding. Geneva, Switzerland: World Health Organization; 2003.

12. Han DH, Shin JM, An S, et al. Long-term Breastfeeding in the Prevention of Allergic Rhinitis: Allergic Rhinitis Cohort Study for Kids (ARCO-Kids Study). Clin Exp Otorhinolaryngol. 2019; 12(3): 301-307.

13. Muraro A, Halken S, Arshad SH, et al. EAAC food allergy and anaphylaxis guidelines. Primary prevention of food allergy. Allergy. 2014; 69(5): 590-601.

14. Lodge CJ, Tan DJ, Lau MX, et al. Breastfeeding and asthma and allergies: a systematic review and meta-analysis. Acta Paediatr. 2015; 104(467): 38-53.

15. Gungor D, Nadaud P, LaPergola CC, et al. Infant milk-feeding practices and food allergies, allergic rhinitis, atopic dermatitis, and asthma throughout the life span: a systematic review. Am J Clin Nutr. 2019; 109(Suppl_7): 772S-799S.

16. Kramer MS. Does breast feeding help protect against atopic disease? Biology, methodology, and a golden jubilee of controversy. J Pediatr. 1988; 112(2): 181-190.

17. Amazouz H, de Lauzon-Guillain B, BourgoinHeck $M$, et al. Infant feeding clusters are associated with respiratory health and allergy at school age in the PARIS birth cohort. Allergy. 2021; 76(4): 1223-1234.

18. Mimouni BA, Mimouni D, Mimouni M, Gdalevich M. Does breastfeeding protect against allergic rhinitis during childhood? A meta-analysis of prospective studies. Acta Paediatr. 2002; 91(3): 275-279.

19. Garcia-Larsen V, lerodiakonou D, Jarrold K et al. Diet during pregnancy and infancy and risk of allergic or autoimmune disease: A systematic review and meta-analysis. PLoS Med. 2018; 15(2): e1002507.

20. Moher D, Liberati A, Tetzlaff J, Altman DG, Group P. Preferred reporting items for systematic reviews and meta-analyses: the PRISMA statement. PLoS Med. 2009; 6(7): e1000097.

21. Wells GB, Shea B, O'Connell J. The
Newcastle-Ottawa Scale (NOS) for Assessing The Quality of Nonrandomised Studies in Meta-analyses [27 Dec 2020]. Available from: http://www.ohri.ca/programs/clinical_epidemiology/oxford.asp.

22. Guyatt GH, Oxman AD, Vist GE, et al. GRADE: an emerging consensus on rating quality of evidence and strength of recommendations. BMJ. 2008; 336(7650): 924-926.

23. Schunemann HJ, Cuello C, Akl EA, et al. GRADE guidelines: 18. How ROBINS-I and other tools to assess risk of bias in nonrandomized studies should be used to rate the certainty of a body of evidence. J Clin Epidemiol. 2019; 111: 105-114.

24. Barnetson RS, Rogers M. Childhood atopic eczema. BMJ. 2002; 324(7350): 1376-1379.

25. Brew BK, Allen CW, Toelle BG, Marks GB. Systematic review and meta-analysis investigating breast feeding and childhood wheezing illness. Paediatr Perinat Epidemiol. 2011; 25(6): 507-518.

26. Kull I, Wickman M, Lilja G, Nordvall SL, Pershagen G. Breast feeding and allergic diseases in infants-a prospective birth cohort study. Arch Dis Child. 2002; 87(6): 478-481.

27. Kramer MS, Matush L, Bogdanovich N, Dahhou M, Platt RW, Mazer B. The low prevalence of allergic disease in Eastern Europe: are risk factors consistent with the hygiene hypothesis? Clin Exp Allergy. 2009; 39(5): 708-716.

28. von Kobyletzki LB, Bornehag CG, Hasselgren $M$, Larsson $M$, Lindstrom $C B$, Svensson $A$. Eczema in early childhood is strongly associated with the development of asthma and rhinitis in a prospective cohort. BMC Dermatol. 2012; 12: 11.

29. Nwaru BI, Takkinen HM, Niemela O, et al. Timing of infant feeding in relation to childhood asthma and allergic diseases. J Allergy Clin Immunol. 2013; 131(1): 78-86.

30. Jelding-Dannemand E, Malby Schoos AM, Bisgaard $\mathrm{H}$. Breast-feeding does not protect against allergic sensitization in early childhood and allergy-associated disease at age 7 years. J Allergy Clin Immunol. 2015; 136(5): 1302-1308 e1301-1313.

31. Chiu CY, Liao SL, Su KW, et al. Exclusive or Partial Breastfeeding for 6 Months Is Associated With Reduced Milk Sensitization and Risk of Eczema in Early Childhood: The PATCH Birth Cohort Study. Medicine (Baltimore). 2016; 95(15): e3391.

32. Ekelund L, Gloppen I, Oien T, Simpson MR. Duration of breastfeeding, age at introduction of complementary foods and allergyrelated diseases: a prospective cohort study. Int Breastfeed J. 2021; 16(1): 5

33. Hummel S, Weiss A, Bonifacio $E$, et al. Associations of breastfeeding with childhood autoimmunity, allergies, and overweight: The Environmental Determinants of Diabetes in the Young (TEDDY) study. Am J Clin Nutr. 2021; 114(1): 134-142.

34. Peroni DG, Piacentini GL, Alfonsi $L$, et al. Rhinitis in pre-school children: prevalence, association with allergic diseases and risk factors. Clin Exp Allergy. 2003; 33(10): 13491354.

35. Obihara CC, Marais BJ, Gie RP, et al. The association of prolonged breastfeeding and allergic disease in poor urban children. Eur Respir J. 2005; 25(6): 970-977.

36. Miyake Y, Arakawa M, Tanaka K, Sasaki S, Ohya Y. Cross-sectional study of allergic disorders associated with breastfeeding in Japan: the Ryukyus Child Health Study. Pediatr Allergy Immunol. 2007; 18(5): 433440

37. Ehlayel MS, Bener A. Duration of breastfeeding and the risk of childhood allergic diseases in a developing country. Allergy Asthma Proc. 2008; 29(4): 386-391.

38. Siriaksorn S, Suchaitanawanit S, Trakultivakorn M. Allergic rhinitis and immunoglobulin deficiency in preschool children with frequent upper respiratory illness. Asian Pac J Allergy Immunol. 2011; 29(1): 73-77.

39. Tamay Z, Akcay A, Ergin A, Guler N. Prevalence of allergic rhinitis and risk factors in 6- to 7-yearold children in Istanbul, Turkey. Turk J Pediatr. 2014; 56(1): 31-40.

40. Huang C, Liu W, Cai J, et al. Breastfeeding and timing of first dietary introduction in relation to childhood asthma, allergies, and airway diseases: A cross-sectional study. J Asthma. 2017; 54(5): 488-497.

41. Chinratanapisit S, Suratannon N, Pacharn P, Sritipsukho P, Vichyanond P. Prevalence and risk factors of allergic rhinitis in children in Bangkok area. Asian Pac J Allergy Immunol. 2019; 37(4): 232-239.

42. Lu C, Norback D, Zhang Y, et al. Furry petrelated wheeze and rhinitis in pre-school children across China: Associations with early life dampness and mould, furry pet keeping, outdoor temperature, PM10 and PM2.5. Environ Int. 2020; 144: 106033.

43. Tong H, Gao L, Deng Y, et al. Prevalence of Allergic Rhinitis and Associated Risk Factors in 6 to 12 Years Schoolchildren From Wuhan in Central China: A Cross-sectional Study. Am J Rhinol Allergy. 2020; 34(5): 632-641.

44. Hu Y, Chen Y, Liu S, et al. Breastfeeding duration modified the effects of neonatal and familial risk factors on childhood asthma and allergy: a population-based study. Respir Res. 2021; 22(1): 41.

45. Li W, Liu Q, Chen Y, et al. Effects of indoor environment and lifestyle on respiratory health of children in Chongqing, China. J Thorac Dis. 2020; 12(10): 6327-6341.

46. Huang CF, Chie WC, Wang IJ. Effect of environmental exposures on allergen sensitization and the development of childhood allergic diseases: A large-scale populationbased study. World Allergy Organ J. 2021; 14(1): 100495.

47. Victora CG, Bahl R, Barros AJ, et al Breastfeeding in the 21 st century: epidemiology, mechanisms, and lifelong effect. Lancet. 2016; 387(10017): 475-490.

48. Vieira Borba V, Sharif K, Shoenfeld 
Y. Breastfeeding and autoimmunity: Programing health from the beginning. Am J Reprod Immunol. 2018; 79(1).

49. Rooks MG, Garrett WS. Gut microbiota, metabolites and host immunity. Nat Rev Immunol. 2016; 16(6): 341-352.

50. Hardjojo A, Shek LP, van Bever HP, Lee BW. Rhinitis in children less than 6 years of age: current knowledge and challenges. Asia Pac Allergy. 2011; 1(3): 115-122.

51. Bousquet J, Schunemann HJ, Samolinski $B$, et al. Allergic Rhinitis and its Impact on Asthma (ARIA): achievements in 10 years and future needs. J Allergy Clin Immunol. 2012; 130(5): 1049-1062.

52. Asher MI, Montefort S, Björkstén B, et al. Worldwide time trends in the prevalence of symptoms of asthma, allergic rhinoconjunctivitis, and eczema in childhood: ISAAC Phases One and Three repeat multicoun- try cross-sectional surveys. Lancet. 2006 368(9537): 733-743.

53. Kim DH, Lim DH, Samra M, Kim EH, Kim JH. How Accurate Are the ISAAC Questions for Diagnosis of Allergic Rhinitis in Korean Children? Int J Environ Res Public Health. 2018; 15(7)

54. Zacharasiewicz A, Douwes J, Pearce N. What proportion of rhinitis symptoms is attributable to atopy? J Clin Epidemiol. 2003; 56(4): 385-390.

55. Mims JW. Epidemiology of allergic rhinitis Int Forum Allergy Rhinol. 2014; 4 Suppl 2: S18-20

56. Kusunoki T, Morimoto T, Nishikomori R, et al Breastfeeding and the prevalence of allergic diseases in schoolchildren: Does reverse causation matter? Pediatr Allergy Immunol. 2010; $21(1$ Pt 1): 60-66.
Kornkiat Snidvongs

Department of Otolaryngology

Faculty of Medicine

Chulalongkorn University

1873 Rama 4 Road

Pathumwan

Bangkok 10330

Thailand

Tel: (+66) 2-256-4103

Fax: (+66) 2-252-7787

E-mail: drkornkiat@yahoo.com 


\section{SUPPLEMENTARY MATERIAL}

Table S1. Search strategies.

\section{PubMed MEDLINE}

\#1 "Breast Feeding"[Mesh]

\#2 "Milk, Human"[Mesh]

\#3 Breast[All Fields] AND Feed*[All Fields]

\#4 Breast-fe*[All Fields]

\#5 Infant fe ${ }^{*}$ [All Fields]

\#6 Infant nutrition* [All Fields]

\#7 Human milk feeding [All Fields]

\#8 \#1 OR \#2 OR \#3 OR \#4 OR \#5 OR \#6 OR \#7

\#9 "Rhinitis, Allergic, Seasonal"[Mesh]

\#10 "Rhinitis, Allergic, Perennial"[Mesh]

\#11 Allergic rhinitis [All fields]

\#12 Hay fever [All fields]

\#13 Allergic rhinoconjunctivitis [All fields]

\#14 \#9 OR \#10 OR \#11 OR \#12 OR \#13

\#8 AND \#14

Web of Science (283), CENTRAL (135), ClinicalTrials.gov (3), WHO International Clinical Trials Registry Platform (6)

\#1 ("breastfeeding" OR "human milk" OR ("breast" AND "feeding") OR "infant feeding" OR "infant nutrition" OR "human milk feeding" OR "breastfed")

\#2 ("allergic rhinitis" OR "seasonal allergic rhinitis" OR "perennial allergic rhinitis" OR "hayfever" OR "hay fever" OR "allergic rhinoconjunctivitis"

\#3 \#1 AND \#2

Table S2. Definition of exclusive breastfeeding,

\section{First Author, Year}

\begin{tabular}{|c|c|c|}
\hline Miyake, 2007 & NA & $<1,1-3,4-11$, and $12+$ months \\
\hline Ehlayel, 2008 & Bread-fed only & 6 months \\
\hline Kramer, 2009 & $\begin{array}{l}\text { Receiving no solids, nonbreast milk, or water or other liquids (other } \\
\text { than vitamins or medications) at all visits }\end{array}$ & 3 months, 6 months \\
\hline Siriaksorn, 2011 & NA & 6 months \\
\hline Jelding-Dannemand, 2015 & $\begin{array}{l}\text { Receiving hypoallergenic formula for less than } 7 \text { days before establi- } \\
\text { shing breastfeeding and not receiving supplementation with formula }\end{array}$ & 6 months \\
\hline Chiu, 2016 & $\begin{array}{l}\text { Receiving breast milk only without additional foods or drinks except } \\
\text { water }\end{array}$ & 6 months \\
\hline Huang, 2017 & $\begin{array}{l}\text { Feeding solely by the mother's breast milk without introducing other } \\
\text { foods or liquids }\end{array}$ & 3 months, 6 months \\
\hline Li, 2020 & NA & 4 months, 6 months \\
\hline
\end{tabular}

Abbreviation: NA, not applicable 
Table S3. Newcastle-Ottawa assessment for Cohort studies.

\begin{tabular}{|c|c|c|c|c|c|c|c|c|c|}
\hline Reference & $\begin{array}{l}\text { (1) Repre- } \\
\text { sentative } \\
\text { exposed } \\
\text { cohort }\end{array}$ & $\begin{array}{l}\text { (2) Selec- } \\
\text { tion of } \\
\text { the non- } \\
\text { exposed } \\
\text { cohort }\end{array}$ & $\begin{array}{l}\text { (3) Ascer- } \\
\text { tainment of } \\
\text { exposure }\end{array}$ & $\begin{array}{l}\text { (4) Dem- } \\
\text { onstra- } \\
\text { tion that } \\
\text { outcome } \\
\text { of interest } \\
\text { was not } \\
\text { present } \\
\text { at start of } \\
\text { study }\end{array}$ & $\begin{array}{l}\text { (5) Compa- } \\
\text { rability of } \\
\text { cohorts on } \\
\text { the basis of } \\
\text { the design } \\
\text { or analysis }\end{array}$ & $\begin{array}{l}\text { (6) Assess- } \\
\text { ment of the } \\
\text { outcome }\end{array}$ & $\begin{array}{l}\text { (7) Was } \\
\text { follow- } \\
\text { up long } \\
\text { enough for } \\
\text { outcomes } \\
\text { to occur }\end{array}$ & $\begin{array}{l}\text { (8) Ad- } \\
\text { equacy of } \\
\text { follow up } \\
\text { of cohorts }\end{array}$ & Total \\
\hline $\begin{array}{l}\text { Kull } \\
(2002)\end{array}$ & 1 & 1 & - & 1 & 1 & 1 & 1 & 1 & 7 \\
\hline $\begin{array}{l}\text { Kramer } \\
\text { (2009) }\end{array}$ & 1 & 1 & 1 & 1 & 1 & 1 & 1 & 1 & 8 \\
\hline $\begin{array}{l}\text { von Vobyletzki } \\
(2012)\end{array}$ & 1 & 1 & 1 & 1 & 1 & - & 1 & 1 & 7 \\
\hline Nwaru (2013) & 1 & 1 & - & - & 2 & 1 & 1 & 1 & 7 \\
\hline $\begin{array}{l}\text { Jelding-Dannemand } \\
\text { (2015) }\end{array}$ & 1 & 1 & 1 & 1 & 1 & 1 & 1 & 1 & 8 \\
\hline $\begin{array}{l}\text { Bion } \\
(2016)\end{array}$ & 1 & 1 & - & 1 & 1 & 1 & 1 & 1 & 7 \\
\hline $\begin{array}{l}\text { Chiu } \\
(2016)\end{array}$ & - & 1 & 1 & 1 & 1 & 1 & 1 & 1 & 7 \\
\hline Ekelund (2021) & 1 & 1 & 1 & 1 & 1 & - & 1 & 1 & 7 \\
\hline Hummel (2021) & 1 & 1 & 1 & 1 & 1 & - & 1 & 1 & 7 \\
\hline
\end{tabular}

Table S4. Newcastle-Ottawa assessment for Cross-sectional studies.

\begin{tabular}{|c|c|c|c|c|c|c|}
\hline Reference & $\begin{array}{l}\text { (1) Representative } \\
\text { exposed cohort }\end{array}$ & $\begin{array}{l}\text { (2) Selection of } \\
\text { the non-exposed } \\
\text { cohort }\end{array}$ & $\begin{array}{l}\text { (3) Ascertainment } \\
\text { of exposure }\end{array}$ & $\begin{array}{l}\text { (4) Comparability } \\
\text { of cohorts on the } \\
\text { basis of the } \\
\text { design or analysis }\end{array}$ & $\begin{array}{l}\text { (5) Assessment of } \\
\text { the outcome }\end{array}$ & Total \\
\hline Peroni (2003) & 1 & 1 & - & 1 & 1 & 4 \\
\hline Obihara (2005) & 1 & 1 & - & 2 & 1 & 5 \\
\hline Miyake (2007) & 1 & 1 & - & 1 & 1 & 4 \\
\hline Ehlayel (2008) & 1 & 1 & - & - & 1 & 3 \\
\hline Siriaksorn (2011) & 1 & 1 & - & 1 & 1 & 4 \\
\hline Tamay (2014) & 1 & 1 & - & 1 & 1 & 4 \\
\hline Huang (2017) & 1 & 1 & - & 2 & 1 & 5 \\
\hline Chinratanapisit (2019) & 1 & 1 & - & 1 & 1 & 4 \\
\hline Han (2019) & 1 & - & 1 & 2 & 1 & 5 \\
\hline Li (2020) & - & 1 & - & 1 & - & 2 \\
\hline Lu (2020) & 1 & 1 & - & 1 & 1 & 4 \\
\hline Tong (2020) & 1 & 1 & - & 1 & - & 3 \\
\hline $\mathrm{Hu}(2021)$ & 1 & 1 & - & 1 & - & 3 \\
\hline Huang (2021) & 1 & 1 & - & 1 & 1 & 4 \\
\hline
\end{tabular}




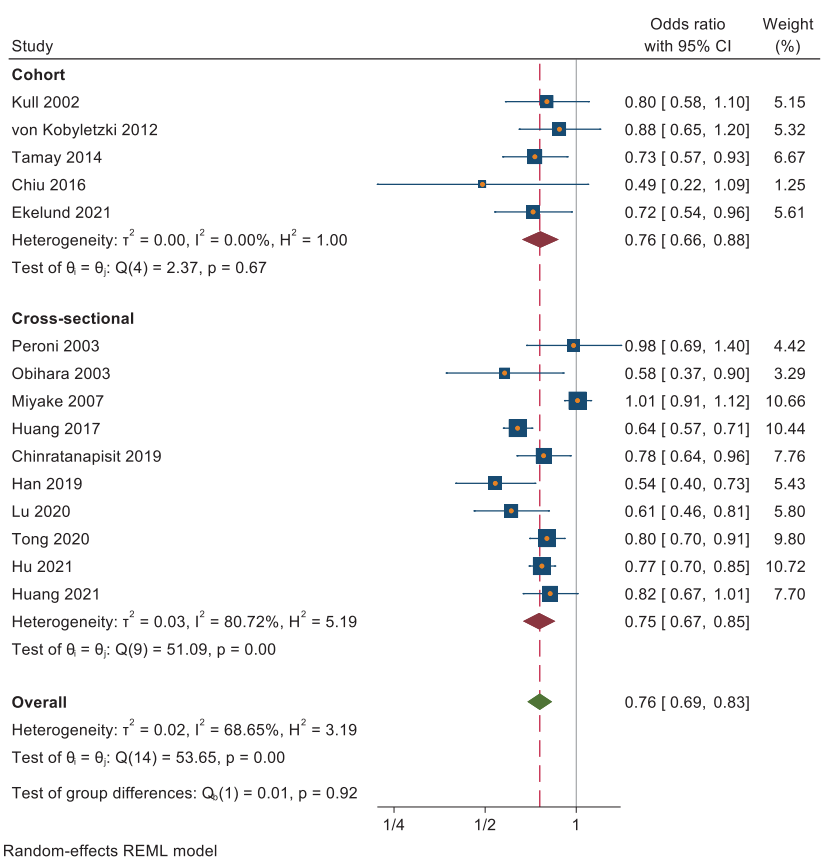

Figure S1. The risk of allergic rhinitis and subgroup analysis by study design: nonexclusive breastfeeding $\geq 6$ months vs $<6$ months.

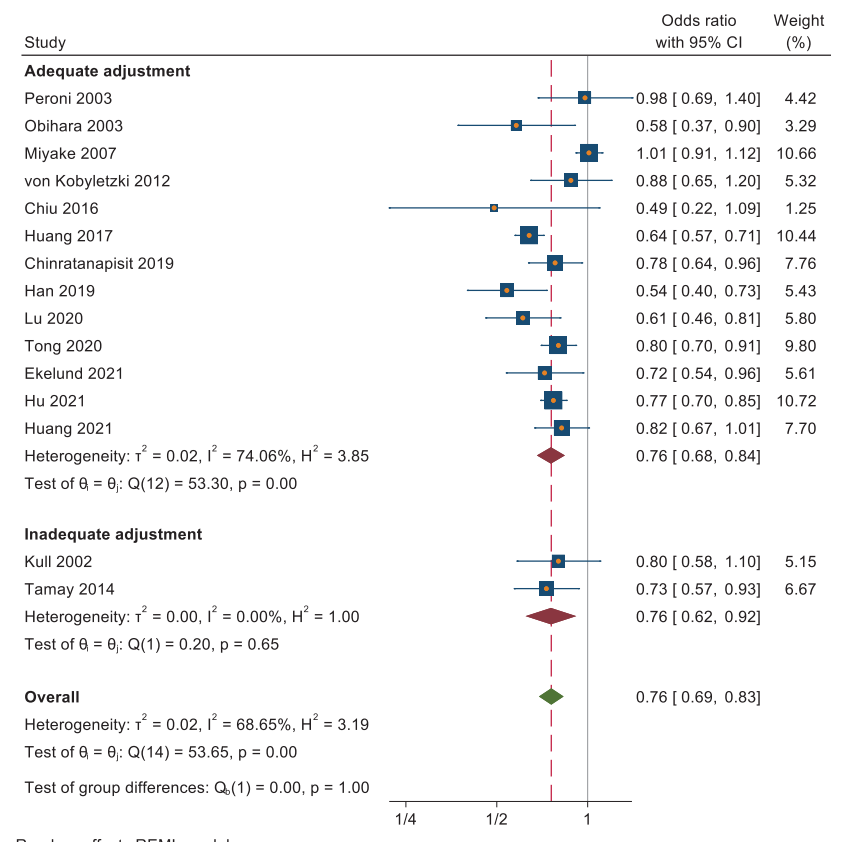

Random-effects REML mode

Figure S2. The risk of allergic rhinitis and subgroup analysis by adjustment for confounders: nonexclusive breastfeeding $\geq 6$ months vs $<6$ months.
Odds ratio
with $95 \% \mathrm{Cl}$
$(\%)$ Study

\section{Africa 2003}

Obihara 2003
Heterogeneity: $\mathrm{T}^{2}=0.00, I^{2}=. \%, \mathrm{H}^{2}=$
Test of $\theta_{1}=\theta_{\mathrm{j}}: \mathrm{Q}(0)=0.00, p=$.

Asia

Miyake 2007

Chiu 2016

Huang 2017

Chinratanapisit 2019

Han 2019

Lu 2020

Tong 2020

Hu 2021

Huang 202

Heterogeneity: $\mathrm{T}^{2}=0.03, \mathrm{I}^{2}=82.30 \%, \mathrm{H}^{2}=5.65$

Test of $\theta=\theta: Q(8)=49.17, p=0.00$

\section{Europe}

Kull 2002

Peroni 2003

von Kobyletzki 2012

Tamay 2014

Ekelund 2021

Heterogeneity: $T^{2}=0.00, I^{2}=0.00 \%, H^{2}=1.00$

Test of $\theta_{1}=\theta_{1}: Q(4)=2.64, p=0.62$

Overall

Heterogeneity: $\mathrm{T}^{2}=0.02, \mathrm{I}^{2}=68.65 \%, \mathrm{H}^{2}=3.19$

Test of $\theta_{1}=\theta_{j}: Q(14)=53.65, p=0.00$

Test of group differences: $Q_{w}(2)=2.04, p=0.36$

Random-effects REML modet

Figure S3. The risk of allergic rhinitis and subgroup analysis by region: nonexclusive breastfeeding $\geq 6$ months vs $<6$ months.

$0.58[0.37,0.90] \quad 3.29$ $0.58[0.37,0.90]$

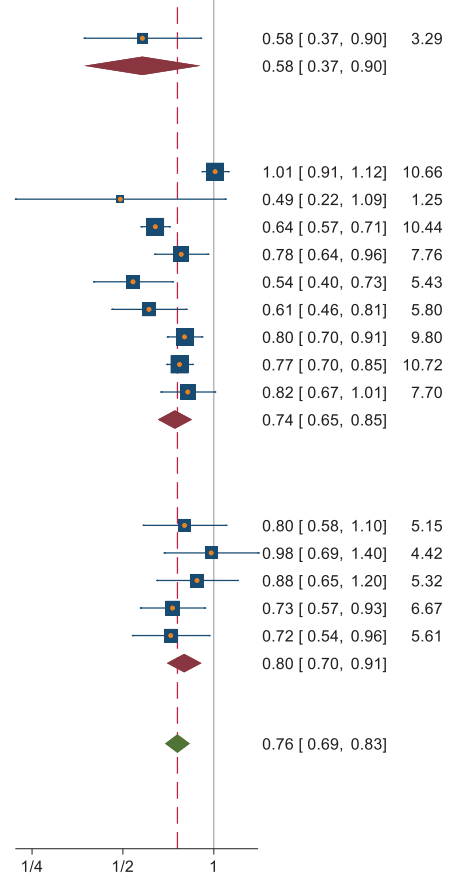

Study

Low quality

Peroni 2003

Tamay 2014

Chinratanapisit 2019

Lu 2020

Tong 2020

Hu 2021

Huang 2021

Heterogeneity: $T^{2}=0.00, I^{2}=0.00 \%, H^{2}=1.00$

Test of $\theta_{1}=\theta_{1}: Q(6)=5.16, p=0.52$

\section{Medium quality}

Kull 2002

Obihara 2003

Miyake 2007

von Kobyletzki 2012

Chiu 2016

Huang 2017

Han 2019

Ekelund 2021

Heterogeneity: $\mathrm{T}^{2}=0.04, \mathrm{I}^{2}=78.57 \%, \mathrm{H}^{2}=4.67$

Test of $\theta_{1}=\theta_{:}: Q(7)=48.31, p=0.00$

Overall

Heterogeneity: $\mathrm{T}^{2}=0.02, \mathrm{I}^{2}=68.65 \%, \mathrm{H}^{2}=3.19$

Test of $\theta_{1}=\theta_{1}: Q(14)=53.65, p=0.00$

Test of group differences: $Q_{0}(1)=0.49, p=0.49$

Random-effects REML mode

Odds ratio Weight with $95 \% \mathrm{Cl} \quad(\%)$

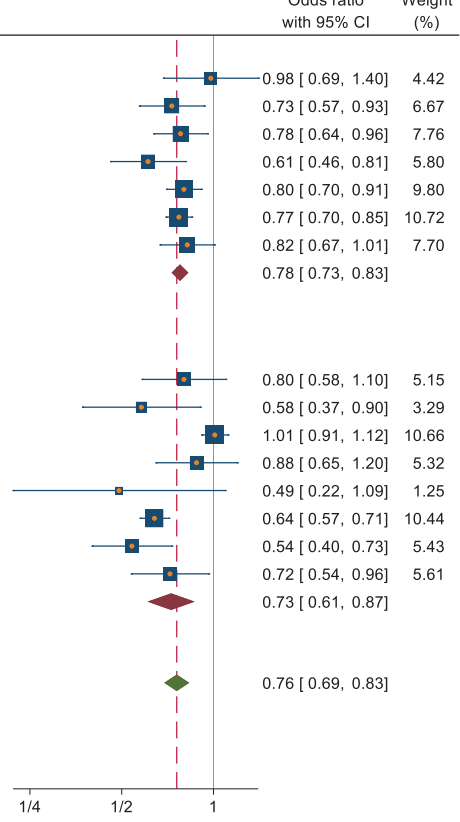

Figure S4. The risk of allergic rhinitis and subgroup analysis by study quality: nonexclusive breastfeeding $\geq 6$ months vs $<6$ months. 


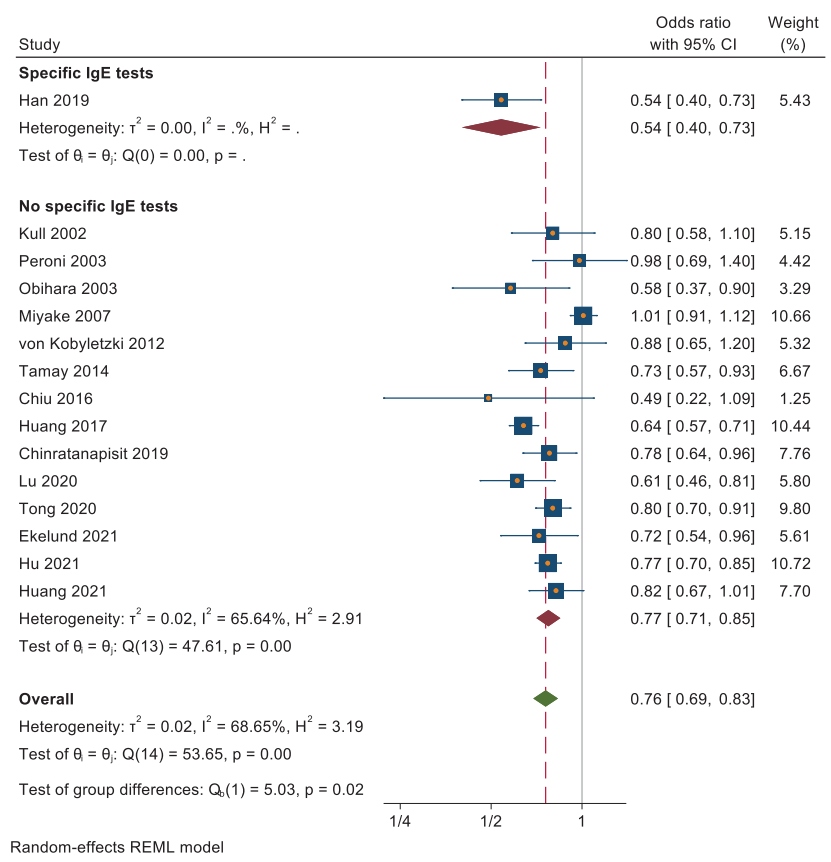

Figure S5. The risk of allergic rhinitis and subgroup analysis by AR diagnostic tools: nonexclusive breastfeeding $\geq 6$ months vs $<6$ months.

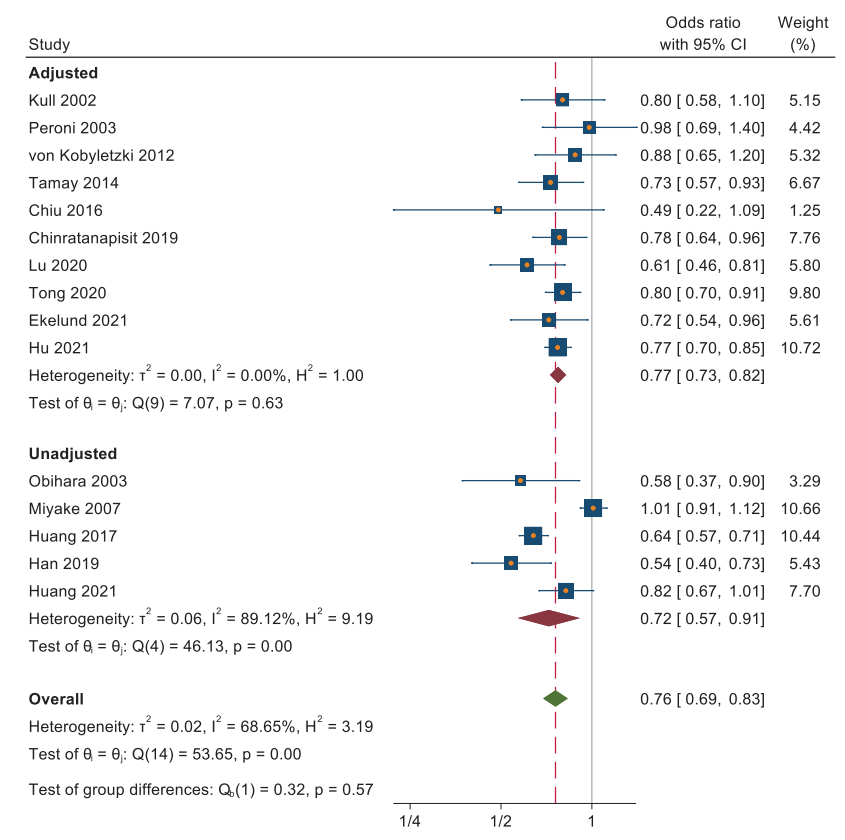

Random-effects REML model

Figure S6. The risk of allergic rhinitis and subgroup analysis by available odds ratio: nonexclusive breastfeeding $\geq 6$ months vs $<6$ months.

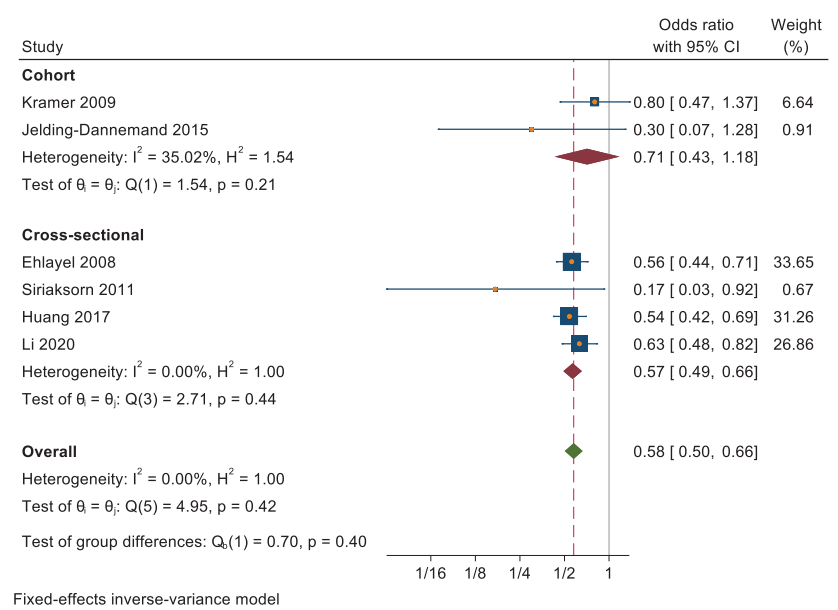

Figure S7. The risk of allergic rhinitis and subgroup analysis by study design: exclusive breastfeeding $\geq 6$ months vs $<6$ months.

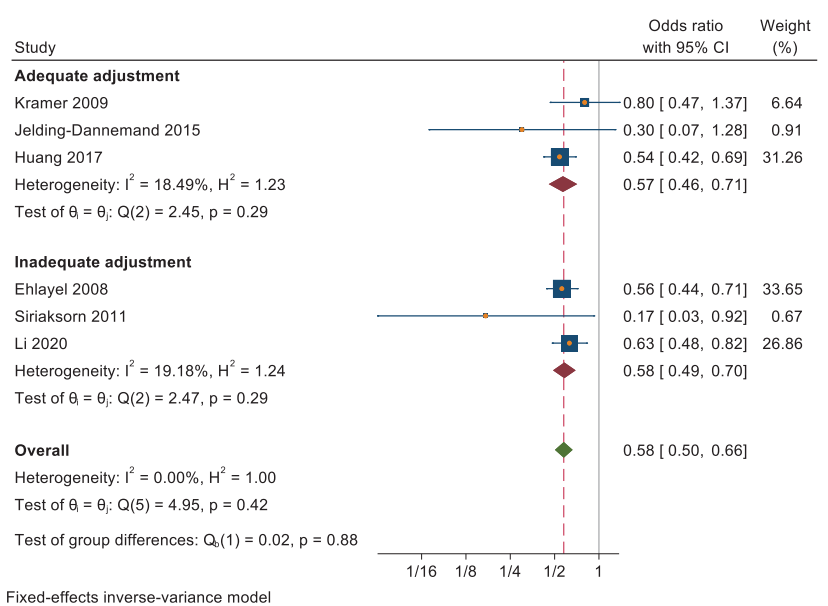

Figure S8. The risk of allergic rhinitis and subgroup analysis by quality of adjustment for confounders: exclusive breastfeeding $\geq 6$ months vs $<6$ months. 


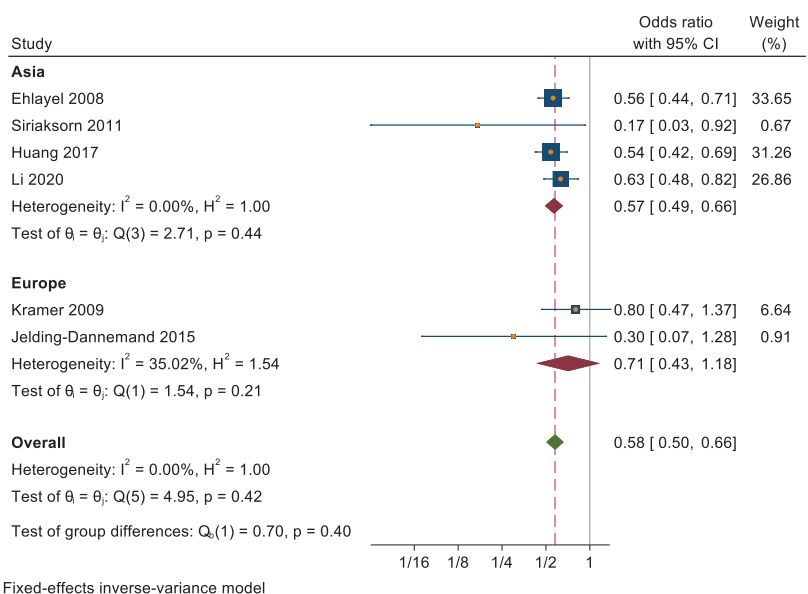

Figure S9. The risk of allergic rhinitis and subgroup analysis by region: exclusive breastfeeding $\geq 6$ months vs $<6$ months.

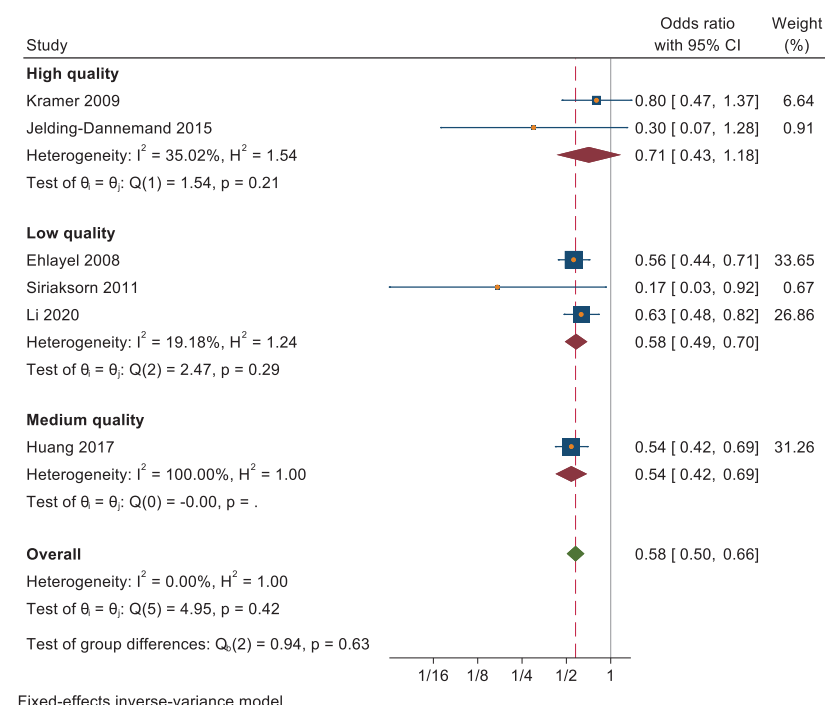

Figure S10. The risk of allergic rhinitis and subgroup analysis by study quality: exclusive breastfeeding $\geq 6$ months vs $<6$ months.

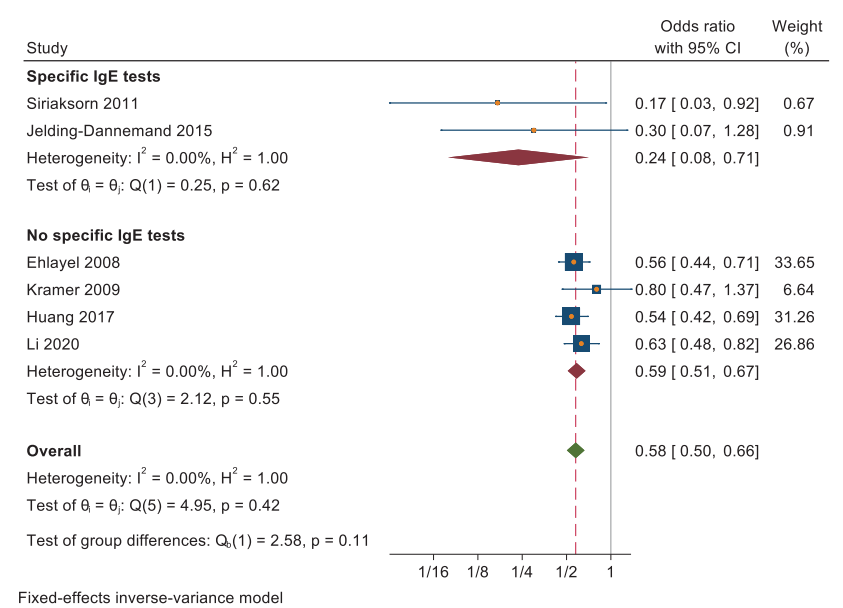

Figure S11. The risk of allergic rhinitis and subgroup analysis by AR diagnostic tools: exclusive breastfeeding $\geq 6$ months vs $<6$ months.

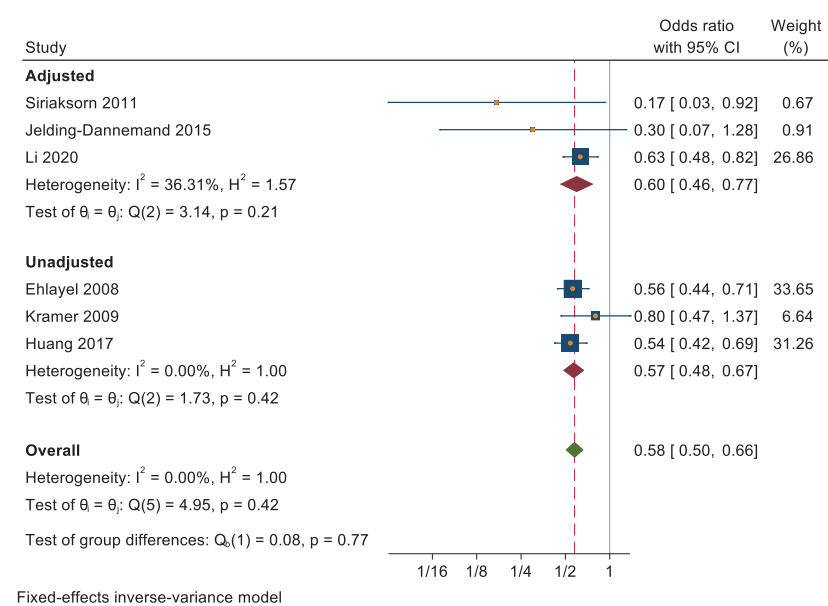

Figure S12. The risk of allergic rhinitis and subgroup analysis by available odds ratio: exclusive breastfeeding $\geq 6$ months vs $<6$ months. 


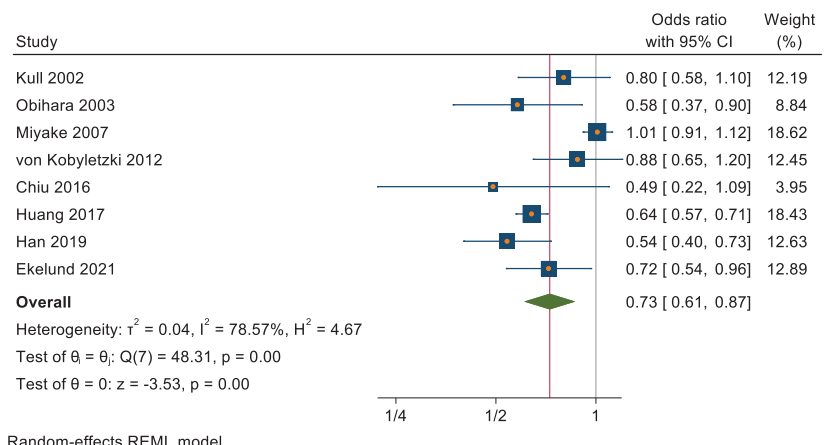

Random-effects REML model

Figure S13. Sensitivity analysis of the risk of allergic rhinitis by removing low-quality studies: nonexclusive breastfeeding $\geq 6$ months vs $<6$ months.

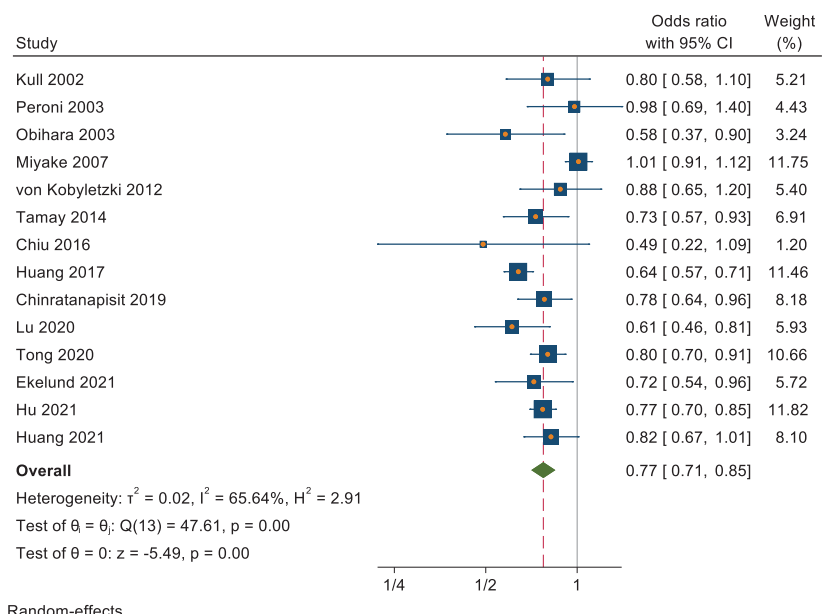

Figure S15. Sensitivity analysis of the risk of allergic rhinitis by removing studies with high-risk populations: nonexclusive breastfeeding $\geq 6$ months vs $<6$ months.

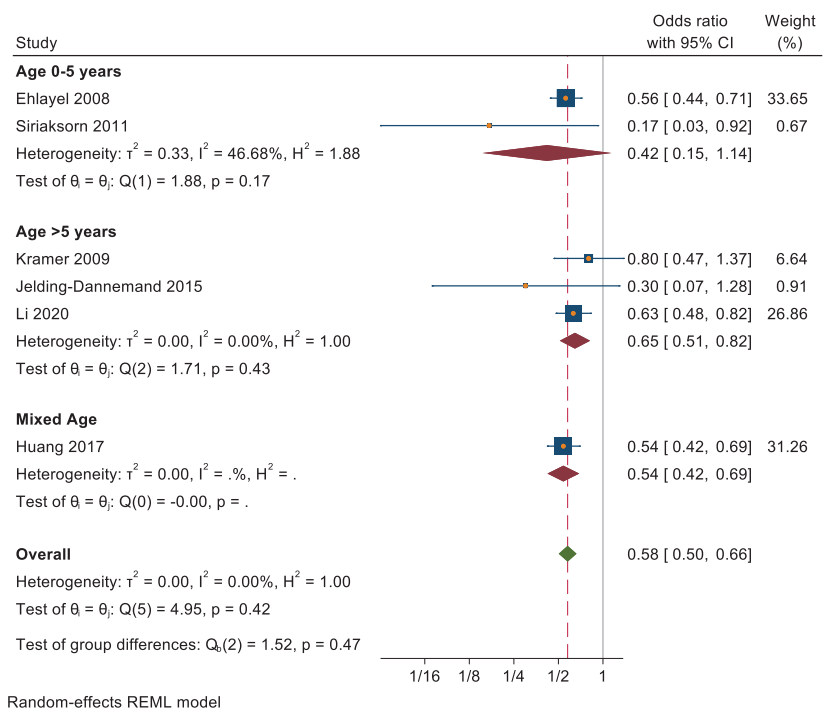

Figure S17. Sensitivity analysis of the risk of allergic rhinitis by using random-effects model: exclusive breastfeeding $\geq 6$ months vs $<6$ months.

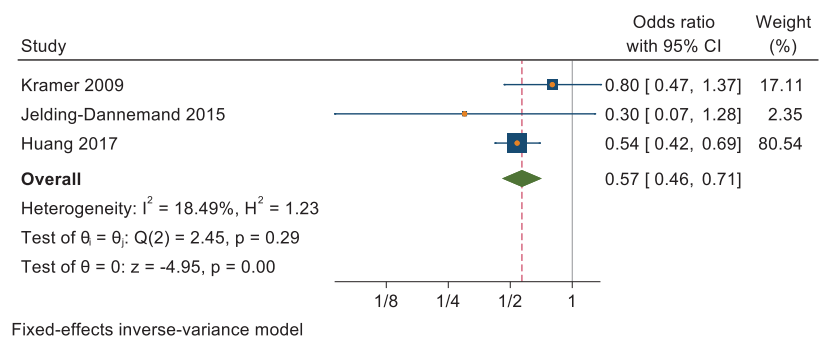

Figure S14. Sensitivity analysis of the risk of allergic rhinitis by removing low-quality studies: exclusive breastfeeding $\geq 6$ months vs $<6$ months.

\begin{tabular}{|c|c|c|c|c|}
\hline Study & & & $\begin{array}{c}\text { Odds ratio } \\
\text { with } 95 \% \mathrm{Cl}\end{array}$ & $\begin{array}{l}\text { Weight } \\
(\%)\end{array}$ \\
\hline Ehlayel 2008 & & -to- & $0.56[0.44,0.71]$ & 33.96 \\
\hline Kramer 2009 & & & $-0.80[0.47,1.37]$ & 6.70 \\
\hline Siriaksorn 2011 & & +1 & $0.17[0.03,0.92]$ & 0.68 \\
\hline Huang 2017 & & - & $0.54[0.42,0.69]$ & 31.55 \\
\hline Li 2020 & & -6 & $0.63[0.48,0.82]$ & 27.11 \\
\hline Overall & & $\bullet$ & $0.58[0.51,0.67]$ & \\
\hline Heterogeneity: $\mathrm{I}^{2}=3.94 \%, \mathrm{H}^{2}=1.04$ & & & & \\
\hline Test of $\theta_{1}=\theta_{j}: Q(4)=4.16, p=0.38$ & & & & \\
\hline Test of $\theta=0: z=-7.64, p=0.00$ & & & & \\
\hline & $1 / 16 \quad 1 / 8$ & $1 / 2$ & & \\
\hline
\end{tabular}

Figure S16. Sensitivity analysis of the risk of allergic rhinitis by removing studies with high-risk populations: exclusive breastfeeding $\geq 6$ months vs $<6$ months.

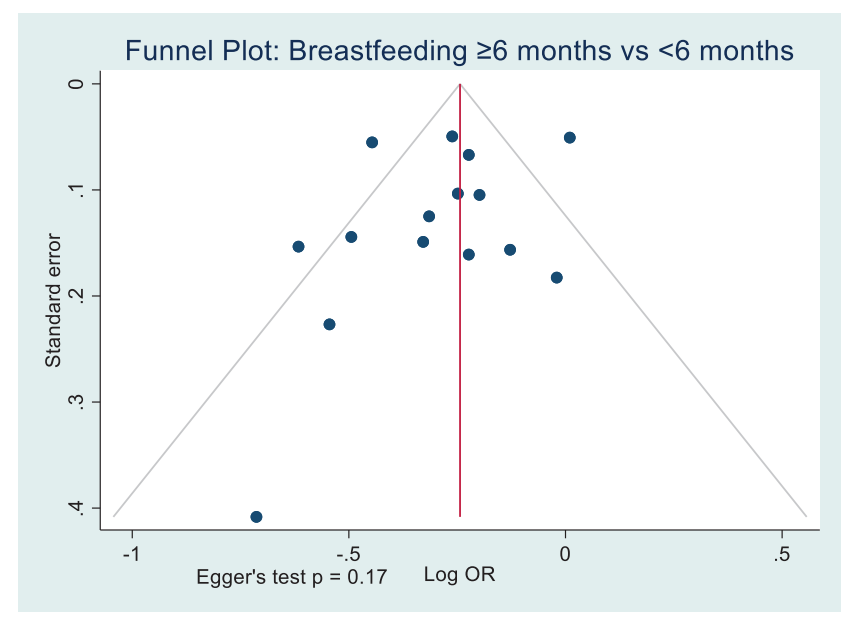

Figure S18. Funnel plot for the risk of allergic rhinitis: nonexclusive breastfeeding $\geq 6$ months vs $<6$ months. Abbreviation: $O R$, odds ratio. 